\title{
Solubility Study of
}

\section{Strontium Fuel Compounds}

This report was prepared as an account of work
sponsored by the United States Government Neither
the United States nor the United States Atomic Energy
Commission nor any of their employees, nor any of
their contractors subcontractors or their employees,
makes any uarranty, express or implied or assumes any
legal lability or responsibility for the accuracy com
pleteness or usefulness of any information, apparatus,
product or process disclosed, or represents that its use
would not infringe privately owned rights

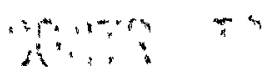

$$
11+1
$$




\section{DISCLAIMER}

This report was prepared as an account of work sponsored by an agency of the United States Government. Neither the United States Government nor any agency Thereof, nor any of their employees, makes any warranty, express or implied, or assumes any legal liability or responsibility for the accuracy, completeness, or usefulness of any information, apparatus, product, or process disclosed, or represents that its use would not infringe privately owned rights. Reference herein to any specific commercial product, process, or service by trade name, trademark, manufacturer, or otherwise does not necessarily constitute or imply its endorsement, recommendation, or favoring by the United States Government or any agency thereof. The views and opinions of authors expressed herein do not necessarily state or reflect those of the United States Government or any agency thereof. 


\section{DISCLAIMER}

Portions of this document may be illegible in electronic image products. Images are produced from the best available original document. 


\section{Solubility Study .}

\section{Strontium Fuel Compounds}

MND-3062-29

\section{Prepared by:}

John H. Gray

For

Division of Isotopes Development

USAEC

$\operatorname{AT}(30-1)-3062$

\footnotetext{
MARTIN MARIETTA CORPORATION

NUCLEAR DIVISION
} 


\section{FOREWORD}

This report is submitted to the U.S. Atomic Energy Commission, Division of Isotopes Development, by the Nuclear Division of the Martin Marietta Corporation in partial fulfillment of Contract AT (30-1)-3062. 
page blank

ii 


\title{
ACKNOWLEDGEMENTS
}

This report contains information contributed over the past year by a number of persons. The contributions of the following people are particularly acknowledged:

\author{
Dr. W. N. McNerney \\ Mr. J. C. Neace \\ Mr. I. E. Mayes
}

Technical support was provided by Messrs. M. Lewis and B. Olsen. 


\section{TABLE OF CONTENTS}

PAGE NO.

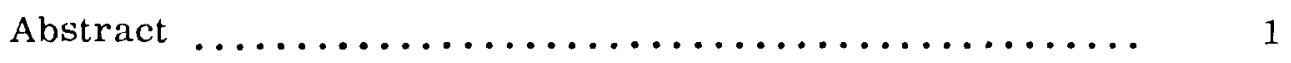

I. Introduction $\ldots \ldots \ldots \ldots \ldots \ldots \ldots \ldots \ldots \ldots \ldots \ldots \ldots$

II. Experimental Methods $\ldots \ldots \ldots \ldots \ldots \ldots \ldots \ldots \ldots \ldots \ldots$

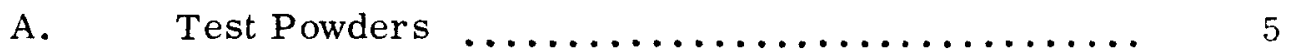

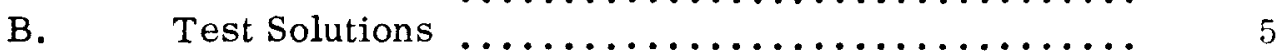

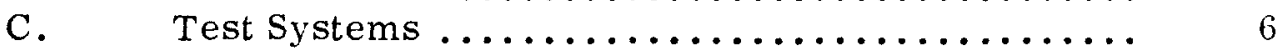

D. Standardization Measurements $\ldots \ldots \ldots \ldots \ldots \ldots .6$

III. Laboratory Studies ....................... 15

IV. Results and Discussion $\ldots \ldots \ldots \ldots \ldots \ldots \ldots \ldots \ldots \ldots \ldots$

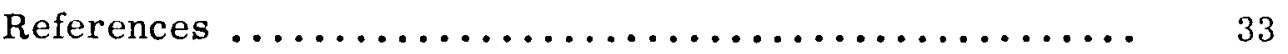




\section{LIST OF TABLES}

TABLE

PAGE NO.

A Rate Equations for Long Term Static Dissolution of Strontium Fuels.

I Chemical Composition of Natural and Synthetic Sea

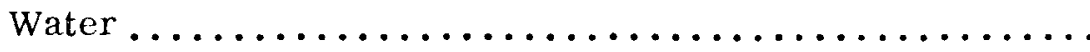

II Particle Size Distribution of $\mathrm{SrF}_{2}, \mathrm{SrTiO}_{3}$ and $\mathrm{Sr}_{2} \mathrm{TiO}_{4}$ Powders

III Rate Equations for Short Term Dynamic Dissolution of Strontium Fuels ....................... 18

IV Long Term Static Dissolution of Strontium Fuels ....... 33

V Short Term Dynamic Dissolution of Strontium Fuels ..... 35 


\section{LIST OF FIGURES}

FIGURE NO.

PAGE NO.

Apparatus for Static Tests $\ldots \ldots \ldots \ldots \ldots \ldots \ldots$.

Apparatus for Dynamic Rate Measurements ........ 13

Static Solubility of Strontium Titanates in Natural

Sea Water ............................ 19

Dynamic Solubility of $\mathrm{SrTiO}_{3} \ldots \ldots \ldots \ldots \ldots \ldots \ldots$

Dynamic Solubility of $\mathrm{Sr}_{2} \mathrm{TiO}_{4} \ldots \ldots \ldots \ldots \ldots \ldots \ldots 21$

Static Solubility of Strontium Titanates in Synthetic

Sea Water ........................... 22

Static Solubility of Strontium Titanates in $0.1 \mathrm{~N} \mathrm{HCl} \ldots 23$

Static Solubility of Strontium Titanates in Deionized

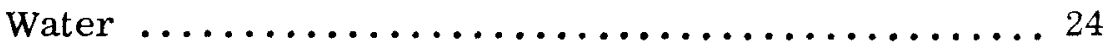

Static Solubility of Strontium Fluoride .......... 25

Static Solubility of $\mathrm{SrF}_{2}$ in $\mathrm{HCl}$ Solutions $\ldots \ldots \ldots 26$

Static Solubility of $\mathrm{SrF}_{2} \ldots \ldots \ldots \ldots \ldots \ldots \ldots \ldots$

Static Solubility of $\mathrm{SrF}_{2}$ in $\mathrm{HCl}$ Solutions $\ldots \ldots \ldots \ldots 28$

Dynamic Solubility of $\mathrm{SrF}_{2} \ldots \ldots \ldots \ldots \ldots \ldots \ldots$

Dynamic Solubility of $\mathrm{SrF}_{2} \ldots \ldots \ldots \ldots \ldots \ldots$ 
The dissolution in synthetic sea water, natural sea water, de-ionized water, and diluted $\mathrm{HCl}$ solutions of strontium titanate, distrontium titanate, and strontium fluoride has been studied. These strontium isotopic fuel compounds were tested in the form of non-radioactive powders containing tracer quantities of strontium-85. Simulation of the fully radioactive strontium-90 (containing 44-50\% inactive strontium) material, utilized in the SNAP generators for terrestrial and space application, was accomplished with the use of the strontium-85 tracer system.

Measurements of the radioactivity release in the different solution media w're performed in the laboratory utilizing test methods similar to those employed by Zigman et al ${ }^{1}$ in their study of the solubility characteristics of strontium titanate pellets. Both static (constant volume and limited circulation) and dynamic (continual passage of fresh solvent through the strontium powder) tests were conducted with the simulated fuel materials. In addition, the effects on the release of strontium of different particle size distributions and elevated temperatures were evaluated.

Relatively large amounts of strontium release, regardless of the solution media, test temperature and average particle size, were observed during the initial short term periods of measurement. This short term, high release rate was also reported by Zigman for strontium titanate pellets even though the total surface area exposed per unit weight of material is much smaller for fuel contained in a large pellet rather than as micron size particles. The strontium release rates (micrograms of fuel per square centimeter of surface area per unit time) did not attain constant values, although a few of the measurements indicated that constant rates would be approached after a hundred or more days of exposure time. The same trends were observed for the short term dynamic tests. This trend observed with the powder agreed with the resuits noted for strontium titanate pellets. Long term strontium dissolution rates (static conditions) for micron size powders of the three test fuels are described as a function of time (in days) by the expressions presented in Table A.

Utilizing the rate equations (Table $\mathrm{A}$ ) and knowing the arerage particle size and distribution of the strontium fuel, the test medium and temperature, an approximate calculation can be made as to the amount of strontium-90 fuel dissolved per unit time.

The solubility rate for $\mathrm{SrTiO}_{3}$ powder in natural sea water was found to differ from that reported by $\mathrm{Zigman}$ for $\mathrm{SrTiO}_{3}$ pellets in natural sea water and also differed from tests conducted by Bloom and Riggs ${ }^{2}$ at $65^{\circ} \mathrm{C}$. In both cases, the measured powder rates were an order of magnitude lower than those previously reported for the pellets. This effect of rate dependence on surface area exposed to the solvent was further substantiated by the order of magnitude difference in the dissolution rate between $5 \mu$ and $35 \mu$ average diameter $\mathrm{SrF}_{2}$ tested under identical conditions. 
Table A

Rate Equations tor Long Term Static Dissolution of Strontium Fuels

NOTE: The Rite Equation is in the form (except where oiherwise noted)

$R=a e^{-b t}+c e^{-d t}+f$

$\mathbf{R}$ is rate expressed as $\mu \mathrm{gms} / \mathrm{cm}^{2} /$ day

$t$ is time expressed in days RATE EQLATION CONSTANTS

\begin{tabular}{|c|c|c|c|c|c|c|c|c|c|}
\hline FUEL & $\begin{array}{l}\text { FIG. NO. }{ }^{(1)} \\
\text { CURVE NO. }\end{array}$ & $\begin{array}{l}\text { TEST } \\
\text { TEMP } \\
\left({ }^{\circ} \mathrm{C}\right)\end{array}$ & $\begin{array}{l}\text { FUEL } \\
\text { PARTIC LE } \\
\text { SIZE HY }\end{array}$ & SOLVENI (2) & a & $\mathrm{b}$ & c & $--\underline{d}$ & $\mathrm{f}$ \\
\hline $\mathrm{SrF}_{2}$ & $9-25$ & 25 & $3 E$ & SSW & 3.055 & $-5.002 \times 10^{-2}$ & $1.553 \times 10^{1}$ & $-2.317 \times 10^{-1}$ & $2.179 \times 10^{-1}$ \\
\hline $\mathrm{SrF}_{2}$ & $9-26$ & 66 & 35 & SSW & $4.172 \times 10^{19}$ & $-4.554 \times 10^{18}$ & 2.260 & $-5.355 \times 10^{-2}$ & $9.366 \times 10^{-1}$ \\
\hline $\mathrm{SrF}_{2}$ & $9-27$ & 25 & 35 & DIW & $8.773 \times 10^{-1}$ & $-1.575 \times 10^{-1}$ & $3.152 \times 10^{-1}$ & $-4.089 \times 10^{-2}$ & $1.104 \times 10^{-2}$ \\
\hline $\mathrm{SrF}_{2}$ & $9-28$ & 66 & 35 & DIW & $3.367 \times 10^{-1}$ & $-1.451 \times 10^{-1}$ & $2.124 \times 10^{-1}$ & $-4.125 \times 10^{-2}$ & $2.210 \times 10^{-2}$ \\
\hline $\mathrm{SrF}_{2}$ & $10-30$ & 25 & 35 & $6 \mathrm{~N} \mathrm{HCl}$ & $1.662 \times 10^{2}$ & $-1.532 \times 10^{-1}$ & $5.398 \times 10^{1}$ & $-4.324 \times 10^{-2}$ & 9.740 \\
\hline $\operatorname{Sr} F_{2}$ & $10-29$ & 66 & 35 & $6 \underline{N} \mathrm{HCl}$ & $4.131 \times 10^{2}$ & $-1.370 \times 10^{-1}$ & $9.585 \times 10^{1}$ & $-2.074 \times 10^{-2}$ & $1.189 \times 10^{1}$ \\
\hline $\mathrm{SrF}_{2}$ & $10-32$ & 25 & 35 & $0.1 \mathrm{~N} \mathrm{HCl}$ & $8.916 \times 10^{1}$ & $-1.785 \times 10^{-1}$ & $3.054 \times 10^{1}$ & $-3.731 \times 10^{-2}$ & 4.022 \\
\hline $\mathrm{SrF}_{2}$ & $10-31$ & 66 & 35 & $0.1 \underline{\mathrm{N}} \mathrm{HCl}$ & $2.675 \times 10^{2}$ & $-3.339 \times 10^{-1}$ & $5.841 \times 10^{1}$ & $-5.062 \times 10^{-2}$ & 4.701 \\
\hline $\mathrm{SrF}_{2}$ & $10-33$ & 25 & 35 & $0.01 \mathrm{~N} \mathrm{HCl}$ & 1.715 & $-6.838 \times 10^{-2}$ & $5.040 \times 10^{1}$ & $-2.129 \times 10^{-2}$ & $3.813 \times 10^{-3}$ \\
\hline $\mathrm{SrF}_{2}{ }^{(3)}$ & $10-34$ & 66 & 35 & $0.01 \underline{\mathrm{NCH}}$ & -1.0344 & 1.0083 & -- & -- & - \\
\hline $\mathrm{SrF}_{2}$ & $11-35$ & 25 & 5 & SSW & $7.791 \times 10^{-1}$ & $-1.420 \times 10^{-1}$ & $1.775 \times 10^{-1}$ & $-3.368 \times 10^{-2}$ & 1. $454 \times 10^{-2}$ \\
\hline $\operatorname{SrF}_{2}$ & $11-36$ & 66 & 5 & SSW & $9.002 \times 10^{-2}$ & -6.381 & $1.283 \times 10^{-1}$ & $-3.454 \times 10^{-2}$ & 1. $186 \times 10^{-1}$ \\
\hline $\mathrm{SrF}_{2}$ & $11-37$ & 66 & 5 & DIW & $9.979 \times 10^{-2}$ & $-2.360 \times 10^{-1}$ & $2.398 \times 10^{-2}$ & $-4.733 \times 10^{-2}$ & $6.918 \times 10^{-4}$ \\
\hline $\operatorname{SrF}_{2}$ & $11-38$ & 25 & 5 & DIW & $2.462 \times 10^{-2}$ & $-8.360 \times 10^{-2}$ & $2.106 \times 10^{-2}$ & $-2.757 \times 10^{-2}$ & $2.831 \times 10^{-4}$ \\
\hline $\mathrm{SrF}_{2}$ & $12-39$ & 66 & 5 & $6 \mathrm{NHCl}$ & $3.339 \times 10^{1}$ & $-1.438 \times 10^{-1}$ & 9.403 & $-2.650 \times 10^{-2}$ & 1.501 \\
\hline $\mathrm{SrF}_{2}$ & $12-40$ & 25 & 5 & $6 \mathrm{~N} \mathrm{HCl}$ & $1.188 \times 10^{1}$ & $-1.873 \times 10^{-1}$ & 6.321 & $-4.622 \times 10^{-2}$ & 7. $.26 \times 10^{-1}$ \\
\hline $\mathrm{SrF}_{2}$ & $12-42$ & 25 & 5 & $0.1 \mathrm{~N} \mathrm{HCl}$ & ․ 260 & $-1.801 \times 10^{-1}$ & 2.770 & $-3.981 \times 10^{-2}$ & $3.325 \times 10^{-1}$ \\
\hline $\mathrm{SrF}_{2}$ & $12-41$ & 66 & 5 & $0.1 \mathrm{NHCl}$ & 3.457 & $-4.3502 \times 1 v^{-2}$ & 7.955 & $-1.956 \times 10^{-1}$ & $4.6 . \times \times 10^{-1}$ \\
\hline $\mathrm{SrF}_{2}$ & $12-44$ & 25 & 5 & $0.01 \underline{\underline{N}}$ HCl & $5.299 \times 10^{-2}$ & $-7.511 \times 10^{-2}$ & $7.915 \times 10^{-2}$ & $-1.463 \times 10^{1}$ & $1.556 \times 10^{-3}$ \\
\hline $\mathrm{SrF}_{2}$ & $12-43$ & 66 & 5 & $0.01 \mathrm{NHCl}$ & $3.101 \times 10^{-2}$ & $-2.230 \times 10^{-1}$ & $7.353 \times 10^{-2}$ & $-5.185 \times 10^{-2}$ & $1.696 \times 10^{-2}$ \\
\hline
\end{tabular}




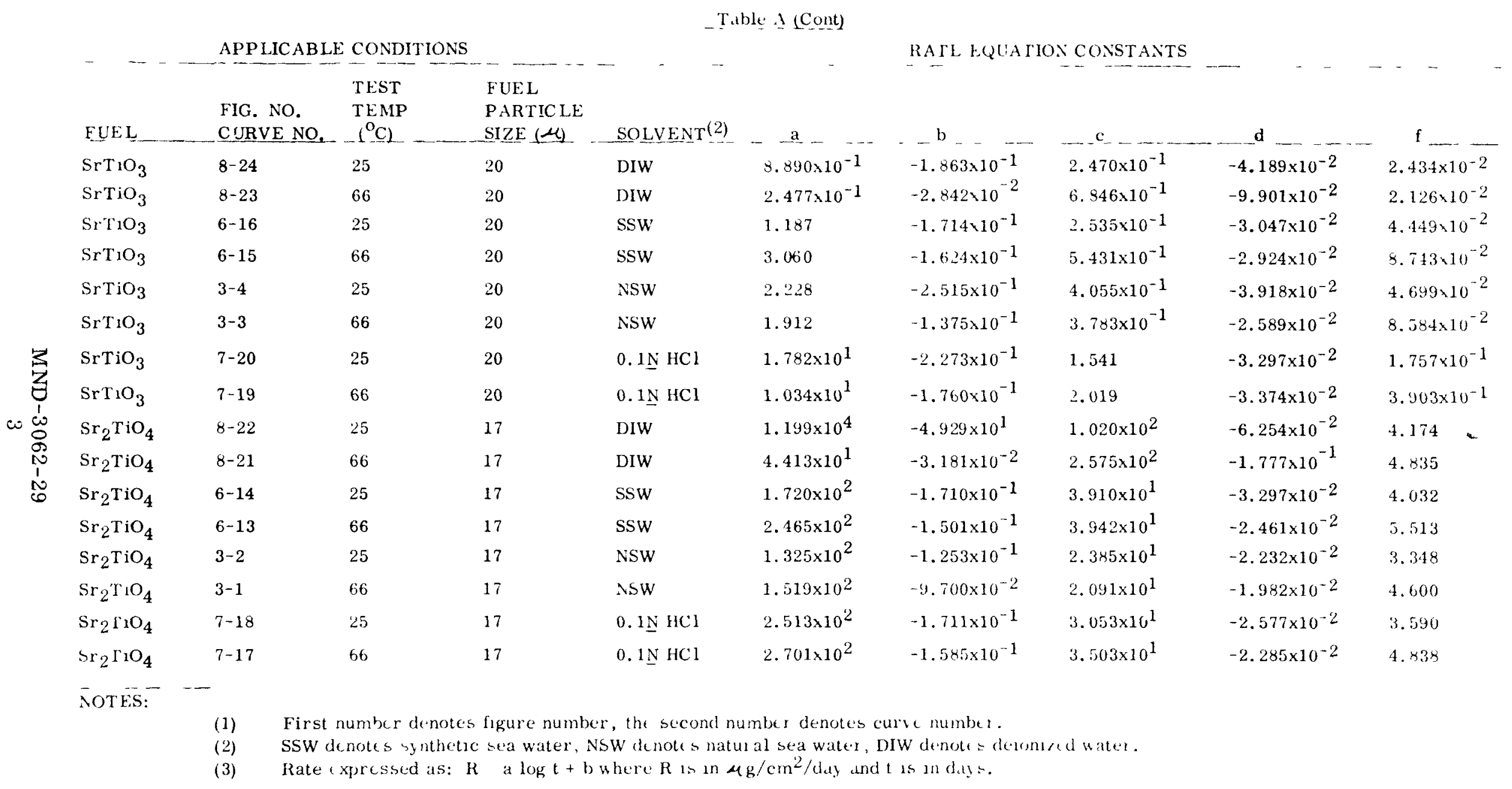




\section{INTRODUCTION}

Strontium titanate, distrontium titanate and strontium fluoride are three radioisotope fuel forms which have been considered for use in thermoelectric generators for space and terrestrial applications. Strontium titanate has already been utilized in SNAP generators located on the earth whereas all three fuels have recently been evaluated for space missions. Accidental release of the isotopic fuel from the encapsulating material will more often result in the exposure of small (micron size) particles rather than exposure in the pellet form. Explosion on the launch pad, partial burnup of the fuel from an aborted launch or during an uncontrolled intact re-entry, and production of micron size particles during re-entry ablation of a burn-up system are typical examples of the fuel forms being ultimately exposed as small particles rather than as large pellets.

Evaluation of the radiobiological and radioecological effects of strontium-90 particles released on land, in water, and in the air requires a knowledge of the dissolution rates in fresh water, salt water, and dilute $\mathrm{HCl}$. Previous experimental work has only been performed on $\mathrm{SrTiO}_{3}$ pellets in salt water. Extrapolation of this $\mathrm{SrTiO}_{3}$ data to the system under consideration was found not to be satisfactory nor could it apply to the anticipated effect of differences on surface area exposed to the dissolving media.

A laboratory study has been performed to define the behavior of these strontium fuel forms in the different test solutions. The effects of temperature and differences in the average particle size on the dissolution rate were considered. Simulation of the dissolution in fresh water systems was approximated by measurements conducted in de-ionized water. Ocean release rates were approximated by tests conducted in natural and synthetic sea water. Inhalation and digestion of small particles suspended in the air resulting in the release of strontium to the human body were simulated by measurements performed with dilute $\mathrm{HCl}$ solutions. Analytical expressions describing both short term and long term dissolution rates in de-ionized water, synthetic sea water, natural sea water, and $\mathrm{HCl}$ solutions were developed.

The effects of oxygen, ionization radiation, and decay impurities on the strontium release during the initial short term dynamic tests and the long term static measurements were not investigated in this study. Oxygen and radiation effects have been evaluated previously for $\mathrm{SrTiO}_{3}$ pellet systems. Additional tests should be performed to evaluate the significance of $\mathrm{Y}$ and $\mathrm{Zr}$ in the lattice structure of strontium compounds. 


\section{EXPERIMENTAL METHODS}

Established techniques were employed in the preparation of strontium test powders, selection and preparation of test solutions, and the calibration of the equipment used to measure the radioactivity release. The utilization of strontium-85 as the tracer isotope in the test compounds enabled a direct measurement of the total amount of strontium fuel released to be performed. A complete description of the materials and apparatus used in the study is presented in this section.

\section{A. Test Powders}

The three strontium compounds prepared for analysis were $\mathrm{SrTiO}_{3}, \mathrm{Sr}_{2} \mathrm{TiO}_{4}$, and $\mathrm{SrF}_{2}$. A 750-gram batch of $\mathrm{SrF}_{2}$ containing 0.5 millicurie of strontium-85 tracer was prepared according to the established synthesis procedure. ${ }^{3}$ After drying overnight at $160^{\circ} \mathrm{C}$, the fluoride was sintered for seven hours at $1200^{\circ} \mathrm{C}$ and then ground using a mortar and pestle. The resulting powder was classified, using Tyler screens, with two fractions being collected. The first was that which passed through a 60 -mesh sieve ( 250 microns) but was retained by an 80 -mesh sieve (177 microns). This fraction was used in the dynamic solubility studies. The average diameter of the particles in this fraction was electronically measured with the Cassella particle size counter and found to be 34.8 microns. The second fraction was that which passed through a 400-mesh sieve ( 37 microns). This fraction was used in the static solubility studies. The average diameter of particles in this fraction, measured with the particle size counter, was 5.1 microns.

One batch of $\mathrm{SrTiO}_{3}$ and one batch of $\mathrm{Sr}_{2} \mathrm{TiO}_{4}$ were prepared using the standard hot cell procedure with one millicurie of strontium-85 tracer added to each. Each batch (approximately 150 grams) was fired for four hours at $950^{\circ} \mathrm{C}$ followed by 12 hours at $1400^{\circ} \mathrm{C}$. After firing, the material was ground in a mortar and sieved using a 60-mesh (250 microns) and a 80-mesh (177 microns) sieve. The average diameter of the $\mathrm{SrTiO}_{3}$ and $\mathrm{Sr}_{2} \mathrm{TiO}_{4}$ particles in this fraction was measured and found to be 96.0 and 100.5 microns respectively. These fractions were used in the dynamic solubility studies. A second fraction, passing through a 80-mesh sieve (177 microns), was used for static dissolution measurements. The average diameter of the $\mathrm{SrTiO}_{3}$ and $\mathrm{Sr}_{2} \mathrm{TiO}_{4}$ particles in this fraction was measured and found to be 20.1 and 16.9 microns, respectively.

\section{B. Test Solutions}

Three types of solvents were tested with the strontium-90 powders. De-ionized water was used to simulate release in fresh and rain water, $6 \mathrm{~N}, 0.1 \mathrm{~N}$, and $0.01 \mathrm{~N} \mathrm{HCl}$ solutions were used to simulate release in the human digestive system, and natural and synthetic sea water were used to simulate release in the oceans. 
A standard formulation of simulated sea water has been devised and specified by the Navy Department 4 . A stock solution, comprised of 10 grams $\mathrm{KCl}$, 45 grams $\mathrm{KBr}, 550$ grams $\mathrm{MgCl}_{2}$, and 110 grams $\mathrm{CaCl}_{2}$, was dissolved in sterile distilled water to make one liter. Simulated sea water was prepared by dissolving 23 grams $\mathrm{NaC} 1,8$ grams $\mathrm{Na}_{2} \mathrm{SO}_{4} \cdot 10 \mathrm{H}_{2} \mathrm{O}$ and 20 milliliters of the above stock solution in sterile distilled water and diluting to a volume of one liter.

In addition to the use of simulated sea water, tests were conducted with natural sea water collected from the ocean one mile off the New Jersey coast. By comparing the data obtained from dissolution experiments conducted under identical conditions, the differences between the artificially prepared mixture and the natural ocean water would be identified. The chemical compositions of the two test sea waters are presented in Table I along with a comparison of standard compositions of elements present in solution in sea water.

\section{TABLE I}

\section{Chemical Composition of Natural and Synthetic Sea Water}

\begin{tabular}{|c|c|c|c|c|}
\hline $\begin{array}{l}\text { Analysis } \\
(\mathrm{mg} / \mathrm{ml})\end{array}$ & $\begin{array}{l}\text { Natural Sea Water } \\
\text { (New Jersey) }\end{array}$ & $\begin{array}{l}\text { Synthetic } \\
\text { Sea Water }\end{array}$ & $\begin{array}{l}\text { Natural Sea Water } \\
\text { (California) }\end{array}$ & $\begin{array}{l}\text { Standard }{ }^{5} \\
\text { Sea Water }\end{array}$ \\
\hline $\mathrm{Na}^{+}$ & 9.49 & 10.19 & -- & 10.56 \\
\hline $\mathrm{Cl}^{-}$ & 17.75 & 23.64 & 19.46 & 19.00 \\
\hline $\mathrm{Mg}^{++}$ & 1.07 & 2.81 & -- & 1.27 \\
\hline $\mathrm{Ca}^{++}$ & 0.39 & 0.79 & -- & 0.40 \\
\hline $\mathrm{Sr}^{++}$ & 0.01 & -- & -- & 0.01 \\
\hline $\mathrm{K}^{+}$ & -- & 0.40 & -- & 0.38 \\
\hline $\mathrm{Br}^{-}$ & -- & 0.60 & -- & 0.07 \\
\hline $\mathrm{S}=$ & -- & 0.80 & -- & 0.88 \\
\hline $\mathrm{pH}$ & 7.65 & -- & 7.9 & -- \\
\hline
\end{tabular}

The dissolution of the strontium fuel powders in the test solutions was conducted under dynamic and static conditions. The long term static test assembly consisted of high temperature polyethylene bottles placed in a constant temperature water, Figure 1. Each powder and test solution in the individual bottles was manually agitated periodically to assure continual contact between the fuel particles and the test solutions. Liquid samples were withdrawn from the bottles and the strontium-85 content per milliliter was determined with a NaI ( $\mathrm{Tl}$ activated) well-type scintillation crystal in 
FTG. 1. APPARATUS FOR STATIC TESTS

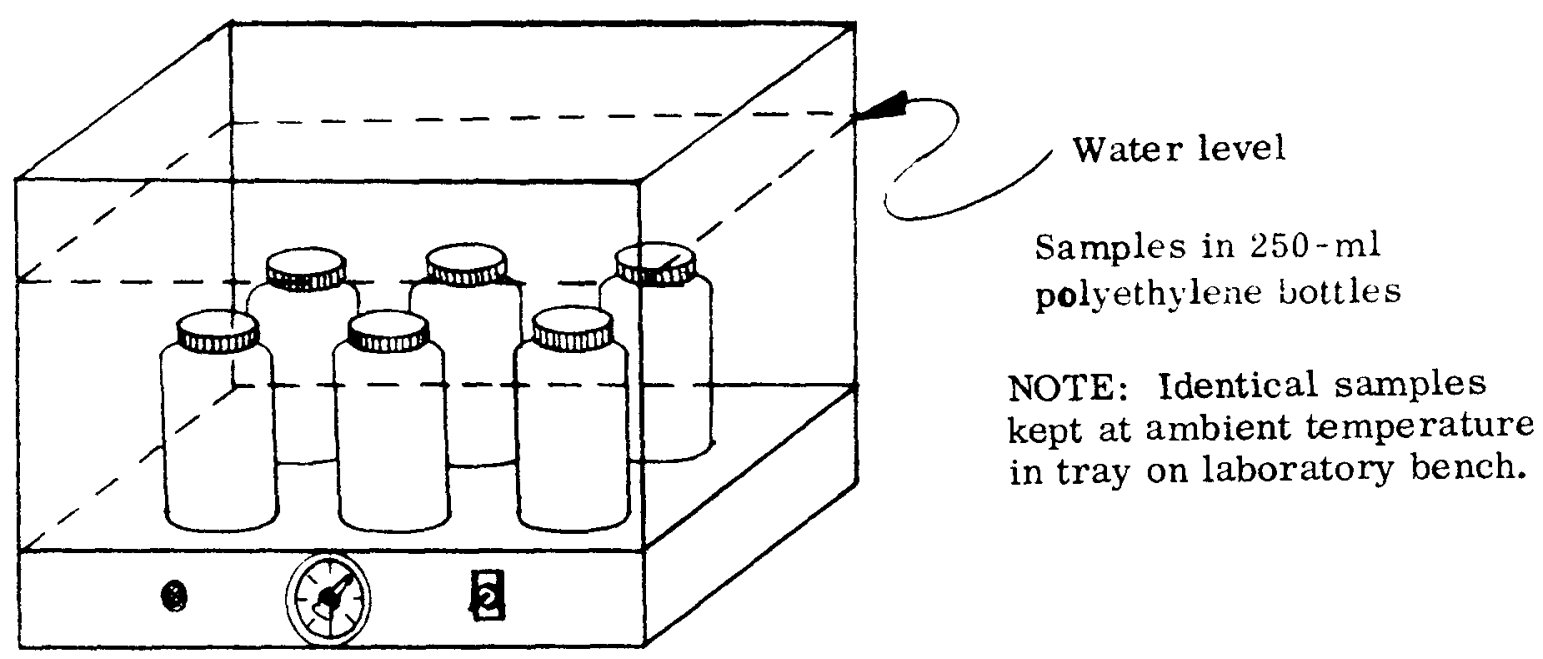

Water bath thermostated at $66^{\circ} \mathrm{C}$

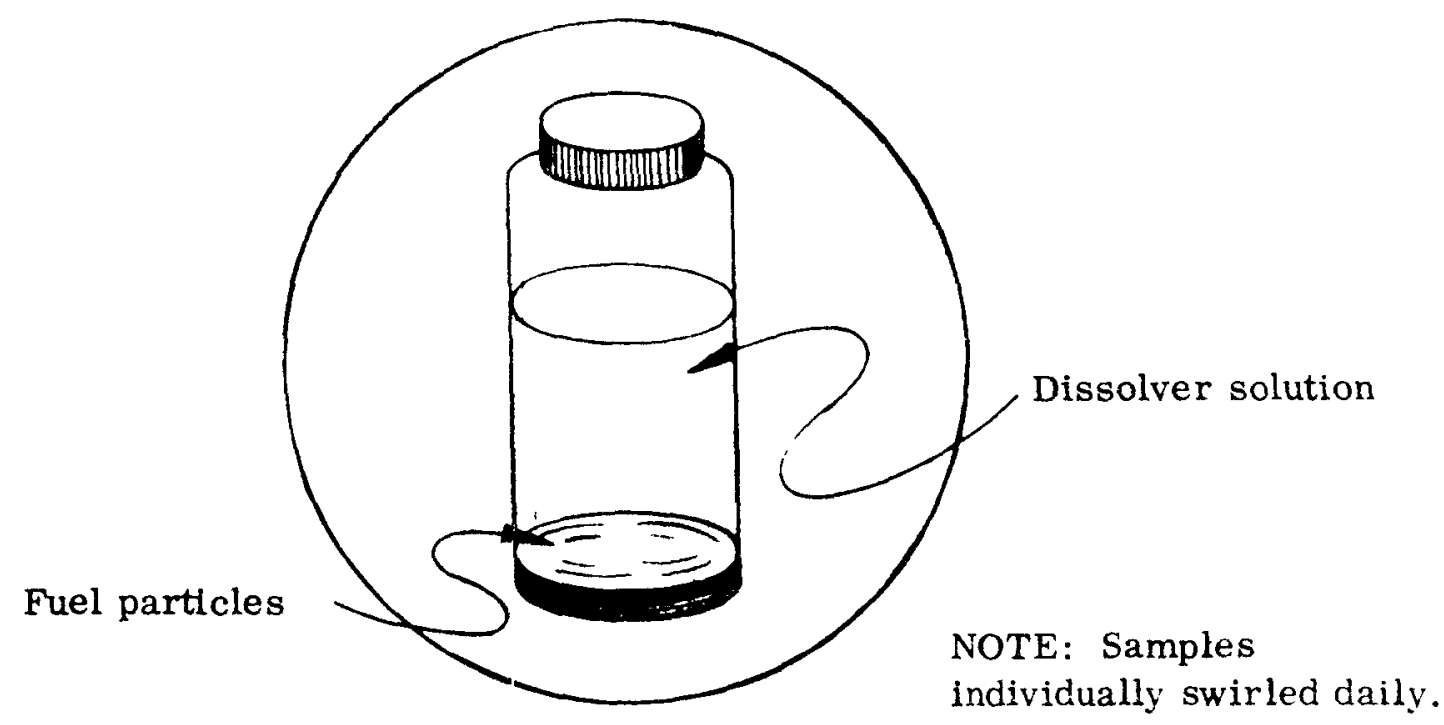

DETAIL

Sample Bottle

MND-3062-29 
conjunction with a 512-multi-channel analyzer.

Since the static solubility tests were essentially a record of the strontium buildup in a limited volume of a given medium at a given temperature, a series of further tests was undertaken to more closely simulate dissolution in large bodies of water where there is essentially an unlimited supply of solvent. The short term dynamic test assembly, used to determine the initial dissolution characteristics of the fuels in the test solutions, is schematically presented in Figure 2. In these dynamic tests, fresh solvent was passed through a bed of strontium particles at a constant rate. The effluent was collected either in beakers for analyses for strontium -85 by carrier precipitation, or passed through a cation exchange resin bed where the strontium-85 was collected for direct counting in the Nal well crystal. Thus, the volume was not recirculated and an infinite amount of solvent was simulated.

D. Standardization Measurements

In order to determine accurately the solubility characteristics of the strontium fuels in the test solutions, evaluation of the reliability in the measurements taken, consideration of potential errors, and determination of the required calibrations, were performed. Significant measurements which have been made for this study include: measurement of the particle size distribution and surface area exposed per gram of fuel, determination of the strontium-85 to total strontium ratio in the test particles, evaluation of the amount of activity absorbed by the polyethylene bottles used in the static tests and calibration of the gamma radiation detection equipment.

Knowledge of the particle size distribution and the total surfact area exposed to the test solution was required in order to derive a rate equation as a function of surface area for a given diameter distribution of particles. The distribution of the particles tested were measured electronically with a Cassella particle size counter. Results of these measurements are presented in Table II.

Tracer quantities of strontium-85 were mixed with the inactive strontium during the preparation of the three test fuels. The utilization of small quantities of radioactive strontium required an accurate determination of the ratio of radioactive strontium to total strontium in order to calculate the strontium release in the test solutions. A weighed quantity of the sintered fuels was dissolved, with aliquots taken and added to counting vials to be used as standards. These standards were further checked by use of weighed quantities of dry fuels. Thus, the specific activity of the tracer fuels was determined and used to calculate the weight of fuel dissolved in each milliliter of test solution. The activity of the tracer used in $\mathrm{Sr} \mathrm{F}_{2}$ was such that each ppm of the fluoride in a milliliter of liquid produced 1.25 net gamma counts in the $0.51 \mathrm{Mev}$ gamma peak of $\mathrm{Sr}-85$ during a four-minute count. 
TABLE II

Particle Size Distribution of $\mathrm{SrF}_{2}, \mathrm{SrTiO}_{3}$, and $\mathrm{Sr}_{2} \mathrm{TiO}_{4}$ Powders

\begin{tabular}{|c|c|c|}
\hline & Fuel Size (Microns) & $\%$ of $\mathrm{P}$ \\
\hline & $\mathrm{SrF}_{2}(-400 \mathrm{mesh})$ & \\
\hline & $<3$ & 19.00 \\
\hline & $3-5$ & 56.00 \\
\hline & $5-7.5$ & 12.75 \\
\hline & $7.5-10$ & 5.50 \\
\hline & $10-12.5$ & 2.75 \\
\hline & $12.5-15$ & 1.50 \\
\hline & $15-17.5$ & 0.75 \\
\hline & $17.5-20$ & 0.50 \\
\hline & $20-25$ & 0.50 \\
\hline & $>25$ & 0.75 \\
\hline$\underset{\substack{Z \\
⿱ 亠 \\
\omega}}{2}$ & $\begin{array}{c}\text { Total } \\
\text { Normalized (per gram) }\end{array}$ & \\
\hline N & $\mathrm{SrTiO}_{3}(-80 \mathrm{mesh})$ & \\
\hline & $<10$ & 7.50 \\
\hline & $10-15$ & 43.75 \\
\hline & $15-20$ & 25.25 \\
\hline & $20-25$ & 8.25 \\
\hline & $25-30$ & 2.75 \\
\hline & $30-35$ & 3.00 \\
\hline & $35-40$ & 2.00 \\
\hline & $40-45$ & 1.25 \\
\hline & $45-50$ & 1.25 \\
\hline & $50-55$ & 1.00 \\
\hline & $55-60$ & 0.50 \\
\hline & $60-65$ & 0.50 \\
\hline & $65-70$ & 0.50 \\
\hline & $70-75$ & 0.25 \\
\hline & $75-80$ & 0.50 \\
\hline & $80-100$ & 0.50 \\
\hline & $100-120$ & 0.25 \\
\hline & $>120$ & 1.00 \\
\hline & Total & \\
\hline
\end{tabular}

Fraction

Diameter Surface Area $\left(\mathrm{cm}^{2}\right)$$$
0.57
$$

2.24

0.0537

0.282

0.80

0.156

0.48

0.31

0.21

0.12

0.09

0.11

$\frac{0.19}{5.12}$

\subsection{4}

0.109

0.089

0.062

0.055

0.079

0.147

1.1967

$1221.13 \frac{\mathrm{cm}^{2}}{\mathrm{gram}}$

0.75

5.47

0.236

2.148

4.44

2.430

1. 86

0.131

0.76

0.653

0.98

0.996

0.75

0.884

0.53

0.709

0.886

0.59

0.53

0.886

0.29

0.519

0.614

0.31

0.716

0.18

0.413

0.39

0.943

0.45

0.28

1.20

20.09

1.273

0.951

$\frac{4.525}{19.893}$

$182 \frac{\mathrm{cm}^{2}}{\text { giam }}$
Volume (cc)

$0.0027 \times 10^{-3}$

$0.0188 \times 10^{-3}$

$0.016 \times 10^{-3}$

$0.027 \times 10^{-3}$

$0.020 \times 10^{-3}$

$0.020 \times 10^{-3}$

$0.017 \times 10^{-3}$

$0.017 \times 10^{-3}$

$0.0298 \times 10^{-3}$

$\frac{0.061 \times 10^{-3}}{0.2293 \times 10^{-3}}$

$0.2340 \mathrm{cc}$

gram

$0.039 \times 10^{-3}$

$0.447 \times 10^{-3}$

$0.709 \times 10^{-3}$

$0.492 \times 10^{-3}$

$0.299 \times 10^{-3}$

$0.539 \times 10^{-3}$

$0.552 \times 10^{-3}$

$0.502 \times 10^{-3}$

$0.701 \times 10^{-3}$

$0.758 \times 10^{-3}$

$0.497 \times 10^{-3}$

$0.639 \times 10^{-3}$

$0.805 \times 10^{-3}$

$0.499 \times 10^{-3}$

1. $219 \times 10^{-3}$

$1.909 \times 10^{-3}$

1. $742 \times 10^{-3}$

$\frac{9.048 \times 10^{-3}}{21.396 \times 10^{-3}}$

$0.1958 \mathrm{cc}$

grim
Grams

$0.0116 \times 10^{-3}$

$0.080 \times 10^{-3}$

$0.069 \times 10^{-3}$

$0.116 \times 10^{-3}$

$0.086 \times 10^{-3}$

$0.086 \times 10^{-3}$

$0.073 \times 10^{-3}$

$0.073 \times 10^{-3}$

$0.128 \times 10^{-3}$

$\frac{0.262 \times 10^{-3}}{0.9846 \times 10^{-3}}$

$0.9846 \times 10^{-3}$

$1.00 \mathrm{gram}$

$0.201 \times 10^{-3}$

2. $284 \times 10^{-3}$

3. $622 \times 10^{-3}$

$2.514 \times 10^{-3}$

$1.530 \times 10^{-3}$

2. $755 \times 10^{-3}$

2. $822 \times 10^{-3}$

$2.565 \times 10^{-3}$

$3.582 \times 10^{-3}$

$3.872 \times 10^{-3}$

$2.539 \times 10^{-3}$

$3.266 \times 10^{-3}$

$4.114 \times 10^{-3}$

$2.549 \times 10^{-3}$

$6.229 \times 10^{-3}$

$9.755 \times 10^{-3}$

$8.903 \times 10^{-3}$

$\frac{46.236 \times 10^{-3}}{109.33 \times \times 10^{-3}}$

$1.00 \mathrm{gram}$

Vormalized (per gram) 
TABLE II (Cont)

\begin{aligned} ut. Bue (Microns) \\ \hline$:=104(-80$ mesh) \\ $<10 \\ 10-15 \\ 15-20 \\ 20-25 \\ 25-30 \\ 30-35 \\ 35-40 \\ 40-45 \\ 45-50 \\ 50-55 \\ 55-60 \\ 60-65 \\ 65-70 \\ 70-75 \\ 75\end{aligned}$

"(i)"malized (per gram)

5.3
$13-60+80$ mesh)
$13-15$
$15-20$
$20-25$
$25-30$
$30-35$
$35-40$
$40-45$
$45-50$
$50-55$
$55-60$
$60-65$
$65-70$
$70-80$
Diameter

Surface Area $\left(\mathrm{cm}^{2}\right)$

Volume (cc)

Grams

30.00

32.50

12.50

11.25

5.75

3.00

1.25

1.00

0.75

0.50

0.25

0.25

0.25

0.25

0.50

3.00

4.06

0.943

2.19

1.596

2.53

1.203

1.58

1.790

1.370

0.98

0.47

0.996

0.553

0.43

0.36

0.568

0.532

0.26

0.433

0.14

0.260

0.16

0.307

0.17

0.358

0.18

$\underline{0.38}$

16.89

0.399

0.886

12.192

$358.57 \mathrm{~cm}^{2}$

$$
\text { gram }
$$

13.75

22.25

5.25

3.25

1.50

0.75

1.00

0.75

0.50

0.75

0.75

0.75

1.00
0.847
2.141
0.835
0.772
0.498
0.331
0.568
0.532
0.433
0.779
0.921
1.074
1.768

\section{$0.157 \times 10^{-3}$ \\ $0.332 \times 10^{-3}$ \\ $0.351 \times 10^{-3}$ \\ $0.672 \times 10^{-3}$ \\ $0.626 \times 10^{-3}$ \\ $0.540 \times 10^{-3}$ \\ $0.345 \times 10^{-3}$ \\ $0.402 \times 10^{-3}$ \\ $0.421 \times 10^{-3}$ \\ $0.379 \times 10^{-3}$ \\ $0.249 \times 10^{-3}$ \\ $0.320 \times 10^{-3}$ \\ $0.403 \times 10^{-3}$ \\ $0.499 \times 10^{-3}$ \\ $1.104 \times 10^{-3}$ \\ $6.800 \times 10^{-3}$ \\ $0.2000 \mathrm{cc}$ \\ gram}

$0.198 \times 10^{-3}$

$0.624 \times 10^{-3}$

$0.313 \times 10^{-3}$

$0.354 \times 10^{-3}$

$0.270 \times 10^{-3}$

$0.207 \times 10^{-3}$

$0.402 \times 10^{-3}$

$0.421 \times 10^{-3}$

$0.379 \times 10^{-3}$

$0.747 \times 10^{-3}$

$0.959 \times 10^{-3}$

1. $208 \times 10^{-3}$

2. $209 \times 10^{-3}$

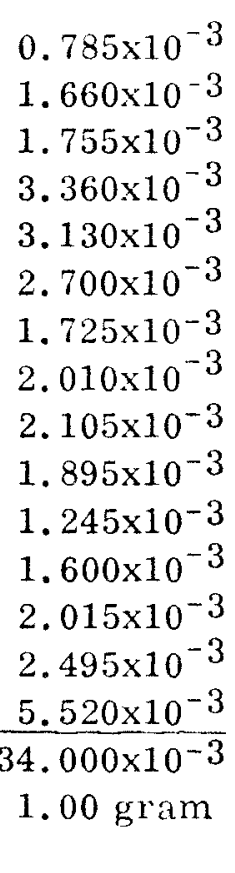

$1.012 \times 10^{-3}$

$3.190 \times 10^{-3}$

1. $600 \times 10^{-3}$

$1.808 \times 10^{-3}$

1. $379 \times 10^{-3}$

$1.058 \times 10^{-3}$

$2.054 \times 10^{-3}$

2. $150 \times 10^{-3}$

$1.937 \times 10^{-3}$

$3.815 \times 10^{-3}$

$4.899 \times 10^{-3}$

$6.173 \times 10^{-3}$

11. $2 \times \times 10^{-3}$ 


\section{TABLE II (Cont)}

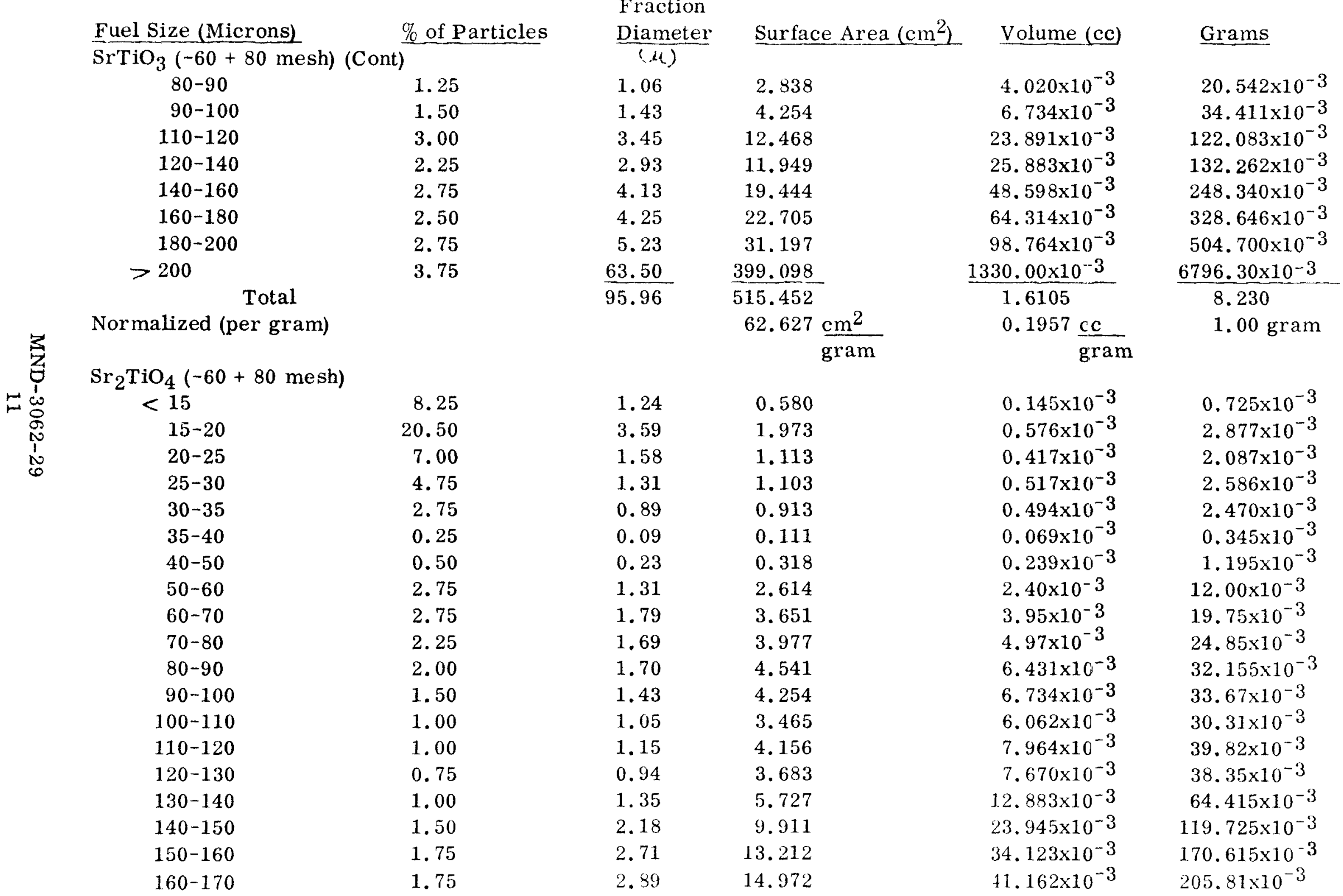


TABLE II (Cont)

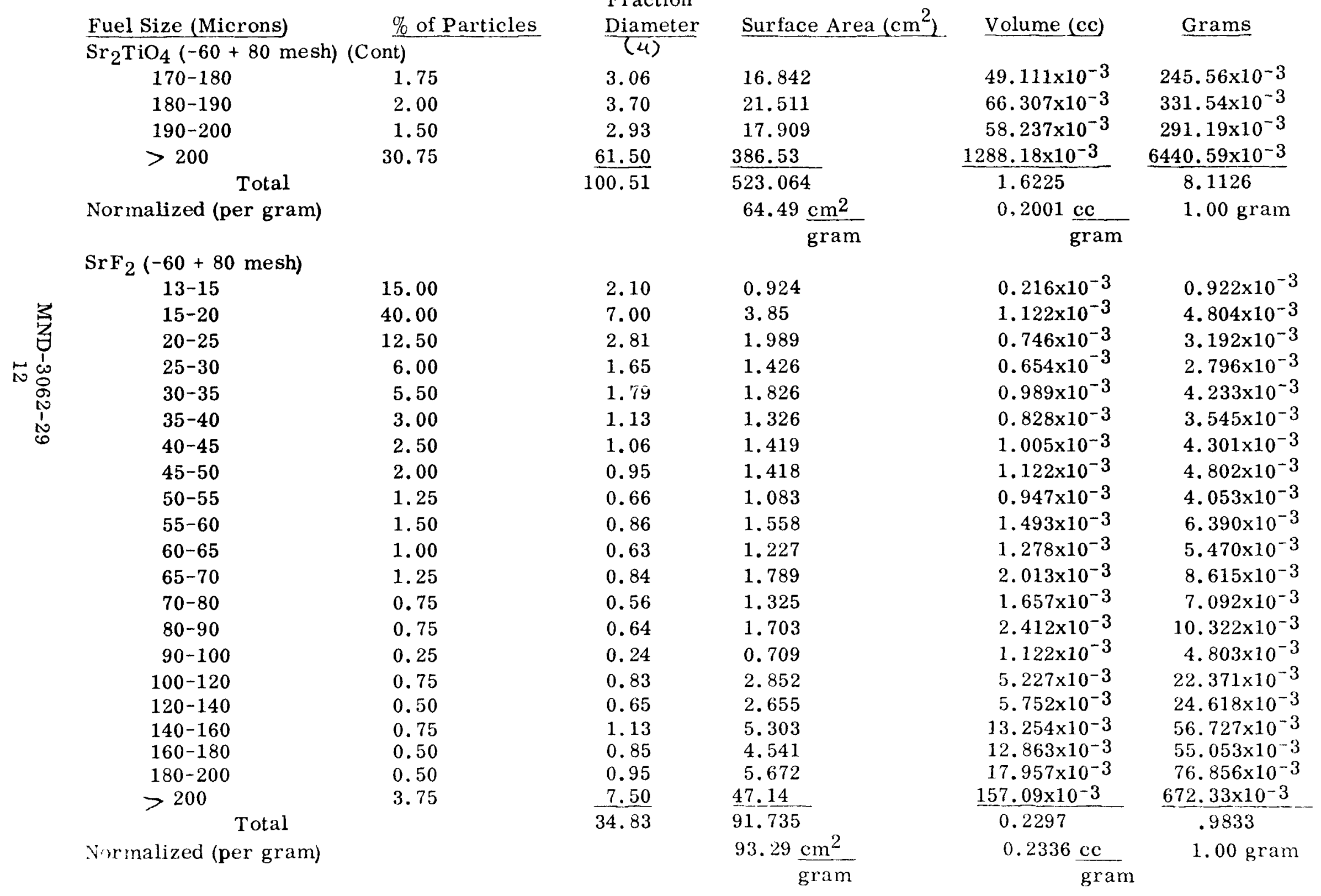




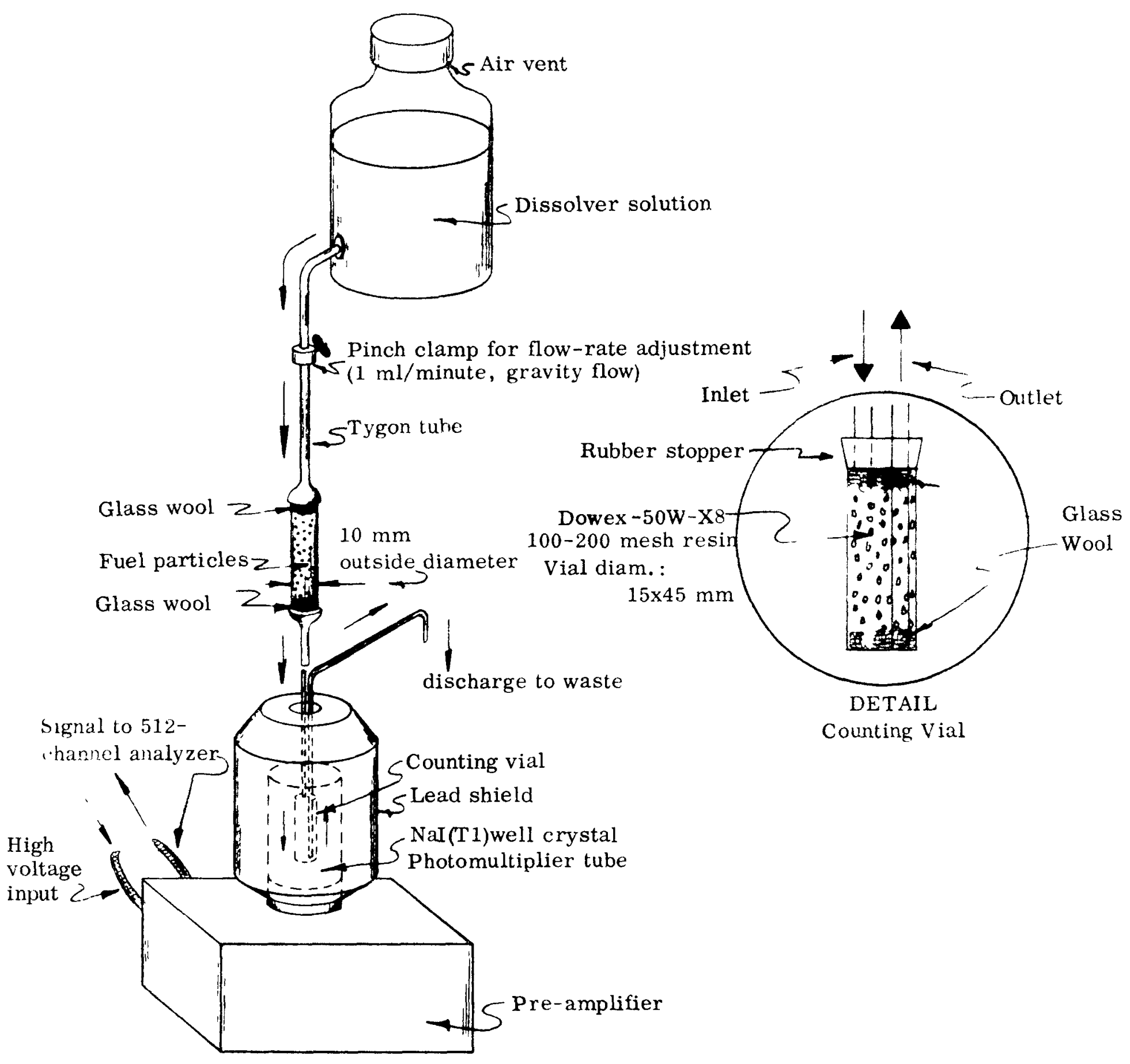

NOTE: Not applicable to sea water samples, since salts in sea water soon exhausted the resin. For sea water samples, the vial and the detector were replaced by a $100-\mathrm{ml}$ beaker. Periodically, the $\mathrm{Sr}-85$ in the beaker was collected by carrier precipitation and filtered through filter paper. The filter paper was then placed in a counting vial for insertion into the well crystal.

FIG. 2. APPARATUS FOR DYNAMIC RATE ME ASUREMENTS 
The counting methods used to determine the specific activity of the test fuels were identical to those employed for counting samples from the dynamic and static solubility studies. Therefore, errors inherent in the counting of radioactive materials, such as geometry factors, self absorption, and efficiency determination, were eliminated. This removal of the need for calibration of the counting technique reduced the uncertainty in the experimental values.

The loss of activity from the test solutions, resulting from incomplete retention by the resin beds during the dynamic tests and/or the absorption by the walls of the polyethylene bottles used in the static tests, was considered. Analysis of the solutions passing through the resin beds was found to contain no detectable strontium. The polyethylene bottles were sectioned after completion of the static tests and the amount of activity detected was equivalent to less than $0.25 \%$ of the activity in solution at any given time during the static measurements. 


\section{LABORATORY STUDIES}

A complete description of the experimental methods used to measure the solubility characteristics of the strontium compounds under static and dynamic conditions is presented in this section.

After preparation of the strontium fluoride powders to be evaluated under static conditions, twenty-gram samples of the 5 and 35 micron fractions were placed in $250 \mathrm{ml}$ high-temperature polyethylene bottles. Five test liquids, deionized water, synthetic sea water, $0.01 \mathrm{~N} \mathrm{HCl}, 0.1 \mathrm{~N} \mathrm{HCl}$, and $6 \mathrm{~N} \mathrm{HCl}$ were prepared. The volume of test liquid added to each bottle was $200 \mathrm{ml}$. One set of ten samples (two mesh sizes, five different liquids) was maintained at $66^{\circ} \mathrm{C}$ in a constant temperature water bath, while an identical set was kept at room temperature. Each sample was thoroughly mixed each day to assure contact between the fluoride and the test solutions.

These tests were begun on September 9, 1965 and completed after a total of 89 days exposure to the solutions. Approximately 2.5 milliliters of the test solution were withdrawn periodically. Each sample was decanted through filter paper with two milliliters of the filtered liquid collected in a glass vial for gamma counting with the 512 multi-channel analyzer. All withdrawn solution was returned to the test bottles after gamma counting.

The solvents used to measure the dissolution characteristics of the titanate fuels under static conditions included deionized water, synthetic sea water, natural sea water, and $0.1 \mathrm{~N} \mathrm{HCl}$. Duplicate samples were prepared for each solvent, for a total of 16 samples. Each sample consisted of nine grams of fuel, with a $\mathrm{SrTiO}_{3}$ average diameter of 20 microns and a $\mathrm{Sr}_{2} \mathrm{TiO}_{4}$ average diameter of 16.9 microns, and $200 \mathrm{ml}$ of dissolver solution in a $250 \mathrm{ml}$ high-temperature polyethylene bottle. One set of eight samples was allowed to stand at room temperature while an identical set was placed in a constant-temperature water bath at $66^{\circ} \mathrm{C}$. These tests were initiated on November 16, 1965 and completed after a total of 161 days exposure to the test solutions.

Approximately 2-1/2 milliliters of the test solutions were periodically withdrawn and filtered through a filter paper, with two milliliters of the filtered solution pipetted into a counting vial. The weight of dissolved fuel present was determined by gamma spectrometry measurements of the $\mathrm{Sr}-85$ content. Weighed quantities of the given fuel were used as standards to calculate the concentration of strontium in solution.

The strontium fluoride used in the dynamic solubility tests was classified with 
a 60-mesh and a 80-mesh sieve (35 micron average diameter). Four test liquids were studied, $0.1 \mathrm{~N} \mathrm{HCl,} \mathrm{synthetic} \mathrm{sea} \mathrm{water,} \mathrm{natural} \mathrm{sea} \mathrm{water,} \mathrm{and} \mathrm{deionized}$ water. All tests were conducted at ambient temperature with a constant flow rate of solvent of one milliliter per minute passing through the fluoride particle containers. The $0.1 \mathrm{~N} \mathrm{HCl}$ solvent passed through 7.61 grams of $\mathrm{SrF}_{2}$ and the dissolved strontium was collected in a four milliliter resin bed of Dowex AG-50W-X8, 100-200 mesh. The $\mathrm{Sr}-85$ content of the resin bed was read directly in the well crystal of the detector. Deionized water passed through 4.93 grams of $\mathrm{SrF}_{2}$ and the dissolved strontum was collected in a four milliliter resin bed of Dowex AG-50W-X8, 100-200 mesh. The Sr-85 content was again read directly in the well crystal of the detector.

The method used for the dynamic measuremen's with $0.1 \mathrm{~N} \mathrm{HCl}$ and deionized water was not applicable to both sea water solvents because of the rapid exhaustion of resin by the salts in sea water. Synthetic sea water was passed through 4.80 grams of $\mathrm{SrF}_{2}$ and collected directly in a $100 \mathrm{ml}$ beaker. The standard radiochemical technique of carrier precipitation was used followed by counting in a vial within the NaI well crystal. The identical method of strontium determination was used with natural sea water after passage through 5.08 grams of fluoride particles.

The solvents used for the dynamic investigation of the titanate fuels at room temperature included deionized water, synthetic sea water, natural sea water, and $0.1 \mathrm{~N} \mathrm{HCl}$. Glass tubes, $22 \mathrm{~cm}$ long $\times 10 \mathrm{~mm}$ OD $(7 \mathrm{~mm} \mathrm{ID})$ were constricted at one end and a pad of glass wool was placed in the constricted end to retain the fuel. Five grams (nominal) of the 100-micron average diameter $\mathrm{Sr}_{2} \mathrm{TiO}_{4}$ fuel and 96 micron average diameter $\mathrm{SrTiO}_{3}$ fuel were cleaned of adhering fines by water classification and then transferred to the glass tubes. The length of the column of fuel particles in the tube was approximately $70 \mathrm{~mm}$. No air bubbles were allowed to form in the column of fuel during loading or during subsequent tests. The fines were collected and theiı weight was quantitatively determined by gamma counting. The weight of the fines was subtracted from the total weight of the samples to determine the true weight of the samples taken. Separate samples of the two fuels were made for each medium, for a total of eight samples.

In each test, a flow rate of one $\mathrm{ml} / \mathrm{min}$ was maintained through the glass tube. The effluent $(\backsim 60 \mathrm{ml})$ was collected each hour for analysis. The effluent was analyzed by carrier precipitation of the Sr-85, followed by centrifuging and a transfer of the precipitate to a counting vial. After counting on the 512-channel analyzer, a correction for chemical yield was made and the weight of fuel dissolved determined using weighed quantities of the given fuel as a standard. 
IV. RESULTS AND DISCUSSION

Results obtained in each of the dynamic and static dissolution experiments are graphically presented in Figures 3 through Figure 14. The data points actually measured during the tests are the points shown on the graphs. Evaluation of the total areas of uncertainty in the measured values resulted in a $\pm 20 \%$ standard deviation for the reported measurements. The dynamic solubility rates have been calculated as a function of micrograms of fuel dissolved per square centimeters of surface area exposed per minute and the static solubility rates have been calculated as a function of micrograms of fuel dissolved per square centimeter of surface area exposed per day.

A computer program was used to obtain the rate equations which best fit the curves drawn from the measured data points. The empirical formula used to approximate all the data curves was of the form:

$$
R=a e^{-b t}+c e^{-d t}+f
$$

where

$$
\begin{aligned}
& \mathrm{R}=\mu \mathrm{g} / \mathrm{cm}^{2} / \text { day or minute } \\
& \mathrm{t}=\text { time in days or minutes }
\end{aligned}
$$

The computer determined the constants which are presented in Table A and Table $\mathbf{H I}$. The short term dynamic rate equations (Table III) can be used to estimate the amount of material dissolved initially under a given set of experimental conditions and the long term static rate equations (Table A) can be used to estimate the quantity of material dissolved after extended exposure to particular solvents. Similarly, knowledge of the particle size distribution (or average diameter) will enable an estimation to be made of the length of time required to completely dissolve a particulate fuel.

A qualitative comparison of the principal experimental findings are summarized according to fuels tested, experimental conditions, and solvents utilized. Quantitative data on the exact differences between the solubility rates can be obtained from the figures depicting the dissolution as a function of time or can be calculated from the rate equations.

Dynamic Tests (Rates)

(1) Synthetic Sea Water

(2) Natural Sea Water

(3) Deionized Water

(4) $0.1 \mathrm{~N} \mathrm{HCl}$

(5) $\mathrm{SrTiO}_{3}(96 \mu)$

(6) $\mathrm{Sr}_{2} \mathrm{TiO}_{4}(100 \mu)$

(7) $\mathrm{SrF}_{2}(35 \mu)$

$$
\begin{aligned}
& \mathrm{Sr}_{2} \mathrm{TiO}_{4}>\mathrm{SrF}_{2}>\mathrm{SrTiO}_{3} \\
& \mathrm{Sr}_{2} \mathrm{TiO}_{4}>\mathrm{SrF}_{2}>\mathrm{SrTiO}_{3} \\
& \mathrm{Sr}_{2} \mathrm{TiO}_{4}>\mathrm{SrF}_{2}>\mathrm{SrTiO}_{3} \\
& \mathrm{Sr}_{2} \mathrm{TiO}_{4}>\mathrm{SrF}_{2}>\mathrm{SrTiO}_{3}
\end{aligned}
$$

$0.1 \mathrm{~N} \mathrm{HCl}>$ D.I. Water $>$ Syn S.W. $>$ Nat. S.W. $0.1 \mathrm{~N} \mathrm{HCl}>$ D.I. Water $>$ Nat. S.W. $>$ Syn. S.W. $0.1 \mathrm{~N} \mathrm{HCl}>$ Syn S.W. > Nat. S.W.> D.I. Water 
TABLE III

Rate Equations for Short Term Dy namic Dissolution of Strontium Fuels

NOTE: The Rate Equation is in the form (except where otherwise noted):

$$
R=a e^{-b t}+c e^{-d t}+f
$$

$R$ is rate expressed as $4 \mathrm{gms} / \mathrm{cm}^{2} / \mathrm{min}$

$t$ is time expressed in minutes

APPLICABLE CONDITIONS

RATE EQUATION CONSTANTS

\begin{tabular}{|c|c|c|c|c|c|c|c|c|c|c|}
\hline & \multicolumn{4}{|c|}{ APPLICABLE CONDITIONS } & \multicolumn{5}{|c|}{ RATE EQUATION CONST ANTS } & \multirow[b]{2}{*}{1} \\
\hline & FUEL & $\begin{array}{l}\text { FIG. NO. } \\
\text { CURVE NO. }\end{array}$ & $\begin{array}{l}\text { TEST } \\
\text { TEMP } \\
\left({ }^{\circ} \mathrm{C}\right)\end{array}$ & $\begin{array}{l}\text { FUEL } \\
\text { PARTICLE } \\
\text { SIZE }(\mu)\end{array}$ & SOLVENT(2) & a & b & c & $\mathrm{d}$ & \\
\hline \multirow{12}{*}{$\begin{array}{l}3 \\
Z \\
8 \\
1 \\
0 \\
0 \\
0 \\
1 \\
1 \\
0\end{array}$} & $\mathrm{SrTiO}_{3}$ & $4-5$ & 25 & 96 & $0.1 \mathrm{~N} \mathrm{HCl}$ & $2.803 \times 10^{11}$ & $-2.002 \times 10^{10}$ & $1.530 \times 10^{-1}$ & $-3.825 \times 10^{-3}$ & $3.233 \times 10^{-2}$ \\
\hline & $\mathrm{SrTiO}_{3}$ & $4-6$ & 25 & 96 & DIW & $3.336 \times 10^{-2}$ & $-3.571 \times 10^{-3}$ & $1.055 \times 10^{-1}$ & $-2.061 \times 10^{-2}$ & 4. $823 \times 10^{-3}$ \\
\hline & $\mathrm{SrTiO}_{3}$ & $4-7$ & 25 & 96 & SSW & $6.045 \times 10^{-2}$ & $-1.460 \times 10^{-2}$ & $2.139 \times 10^{-2}$ & $-2.887 \times 10^{-3}$ & $2.876 \times 10^{-3}$ \\
\hline & $\mathrm{SrTiO}_{3}(3)$ & $4-8$ & 25 & 96 & NSW & $2.988 \times 10^{-3}$ & $-3.5 \times 10^{-7}$ & -1.7744 & $-2.646 \times 10^{-3}$ & - \\
\hline & $\mathrm{Sr}_{2} \mathrm{TiO}_{4}$ & $5-9$ & 25 & 100.5 & $0.1 \mathrm{~N} \mathrm{HCl}$ & $2.206 \times 10^{13}$ & $-1.201 \times 10^{10}$ & $1.811 \times 10^{1}$ & $-3879 \times 10^{-3}$ & 2.382 \\
\hline & $\mathrm{Sr}_{2} \mathrm{TiO}_{4}$ & $5-10$ & 25 & 100.5 & DIW & $1.991 \times 10^{14}$ & $-2.291 \times 10^{11}$ & $4.857 \times 10^{-1}$ & $-4.045 \times 10^{-3}$ & $2.857 \times 10^{-1}$ \\
\hline & $\mathrm{Sr}_{2} \mathrm{TiO}_{4}^{(4)}$ & $5-11$ & 25 & 100.5 & $\mathrm{NSW}$ & $-3.678 \times 10^{-1}$ & $4.807 \times 10^{-1}$ & -- & $\ldots$ & - \\
\hline & $\mathrm{Sr}_{2} \mathrm{TiO}_{4}^{(4)}$ & $5-12$ & 25 & 100.5 & SSW & $-3.859 \times 10^{-1}$ & $3.280 \times 10^{-1}$ & $\ldots$ & -- & $\cdots$ \\
\hline & $\mathrm{SrF}_{2}$ & $13-45$ & 25 & 35 & $0.1 \mathrm{~N} \mathrm{HCl}$ & $7.232 \times 10^{-1}$ & $-7.903 \times 10^{-2}$ & 1.864 & $-2.153 \times 10^{-2}$ & 1.480 \\
\hline & $\mathrm{SrF}_{2}^{2}$ & $13-46$ & 25 & 35 & $\mathrm{DIW}$ & $1.716 \times 10^{-5}$ & $-1.058 \times 10^{-1}$ & $7.100 \times 10^{-2}$ & $-2.000 \times 10^{-2}$ & $6.550 \times 10^{-2}$ \\
\hline & $\mathrm{SrF}_{2}$ & $14-47$ & 25 & 35 & NSW & $8.383 \times 10^{9}$ & $-1.983 \times 10^{8}$ & $8.430 \times 10^{-2}$ & $-1.766 \times 10^{-3}$ & $9.940 \times 10^{-2}$ \\
\hline & $\mathrm{SrF}_{2}$ & $14-48$ & 25 & 35 & SSW & $5.900 \times 10^{-2}$ & $-1.551 \times 10^{-1}$ & $1.190 \times 10^{-1}$ & $-2.000 \times 10^{-2}$ & $1.100 \times 10^{-1}$ \\
\hline
\end{tabular}

Notes (1)

(2)

First number denotes figure number, the second number denotes curve number.

SSW denotes synthetic sea water, NSW denotes natural sea water; DIW denotes deionized water.

Rate expressed as $\mathrm{R}=\mathrm{a}+\mathrm{bt}+10^{\mathrm{c}+\mathrm{dt}}$ where $\mathrm{R}$ is in $4 \mathrm{~g} / \mathrm{cm}^{2} / \mathrm{min}$ and $\mathrm{t}$ is in minutes.

(4) Rate expressed as $R=a \log t+b$ where $R$ is in $\mu \mathrm{g} / \mathrm{cm}^{2} / \mathrm{min}$ and $t$ is in minutes. 


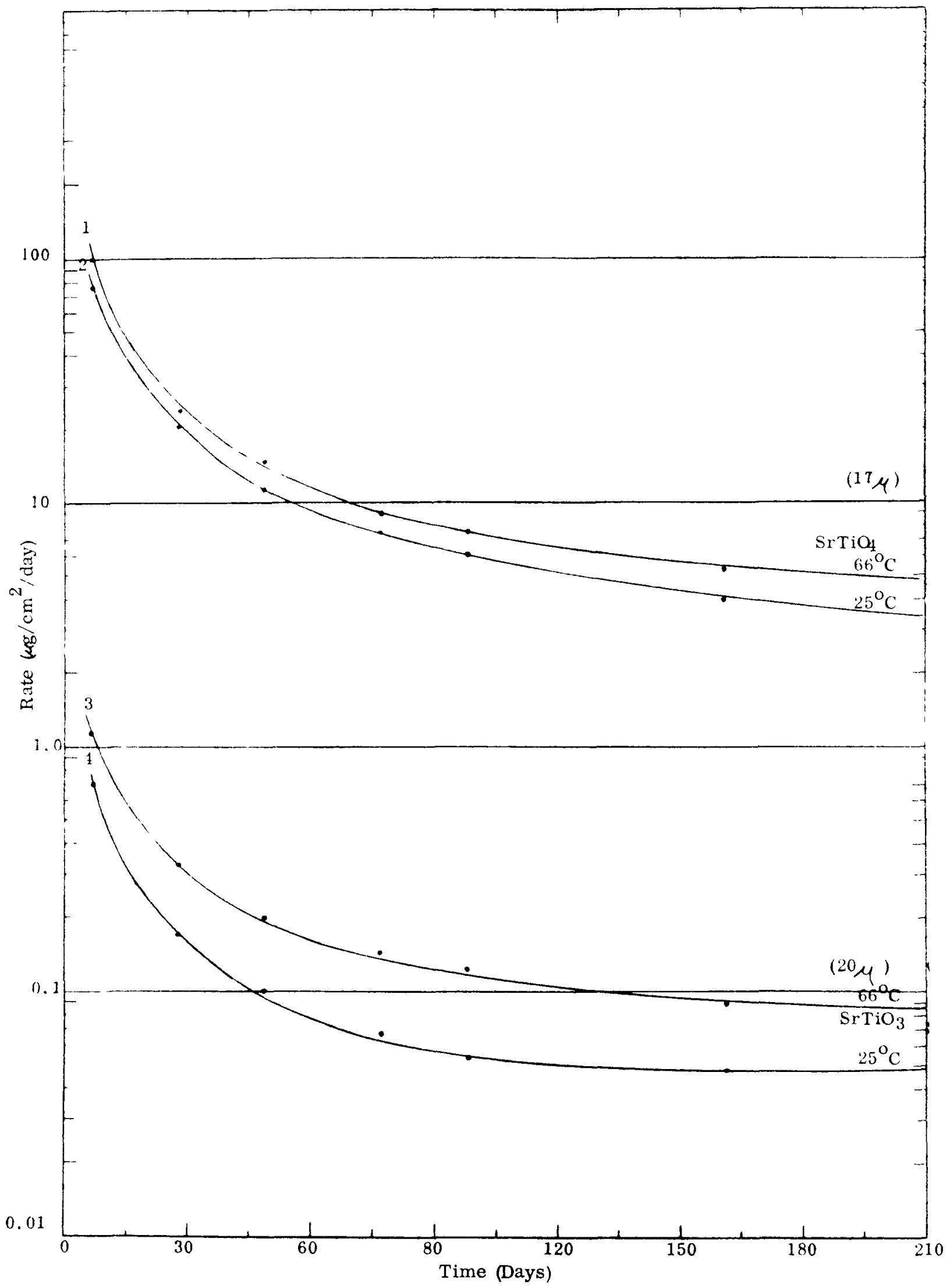

FIG. 3. STATIC SOLUBILITY OF STRONTIUM TITANATES IN NATURAL SEA WATER 


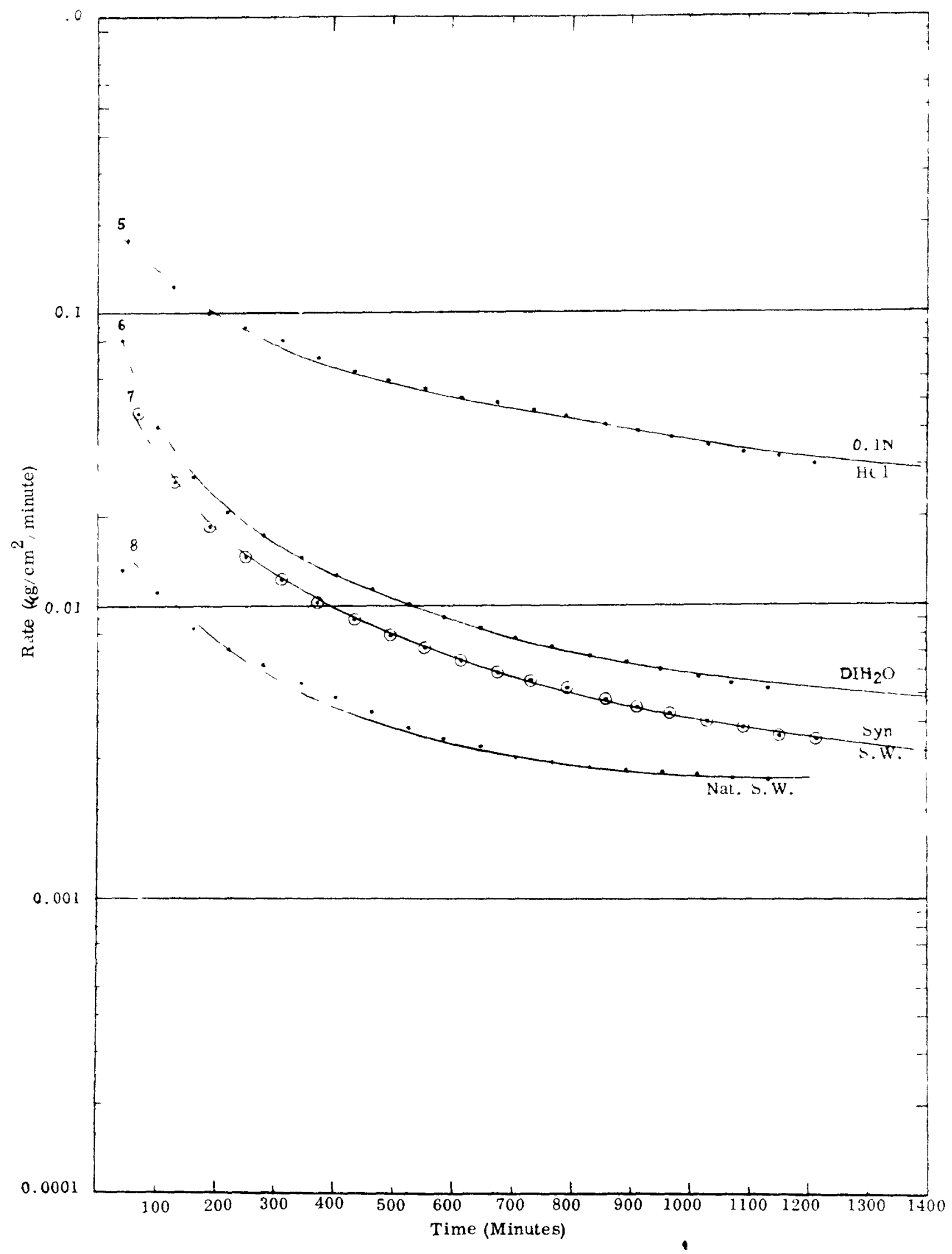

FIG. 4. DYNAMIC SOLUBILITY OF $\mathrm{SrTiO}_{3}$ (AVERAGE PARTIClE SIZE OF 96\%) 


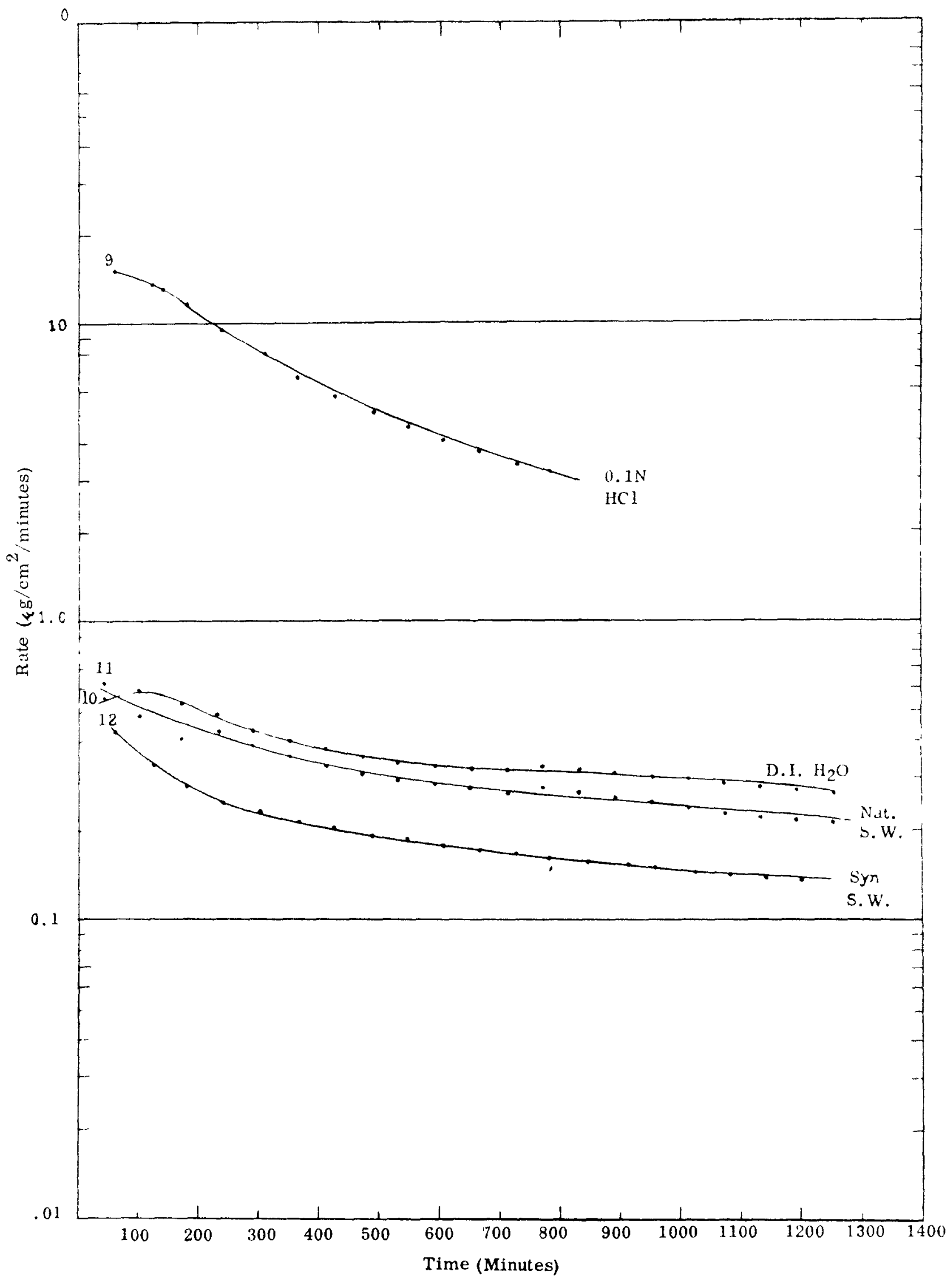

FIG. 5. DYNAMIC SOLUBILITY OF $\mathrm{Sr}_{2} \mathrm{TiO}_{4}$ (AVERAGE PARTICLE SIZE 100.5 $\mu$ ) 


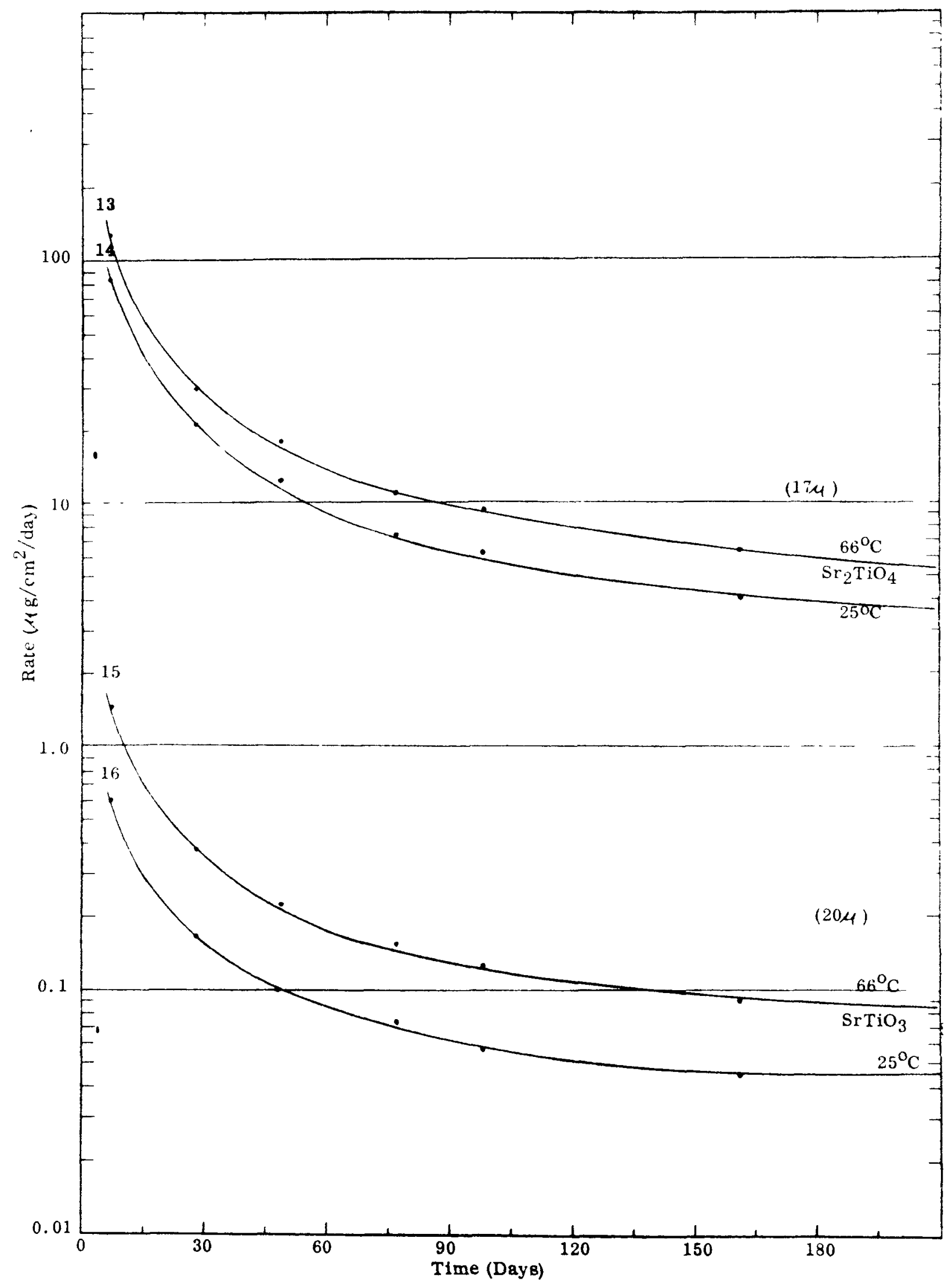

FIG. 6. STATIC SOLUBILITY OF STRONTIUM TITANATES IN SYNTHETIC SEA WATER 


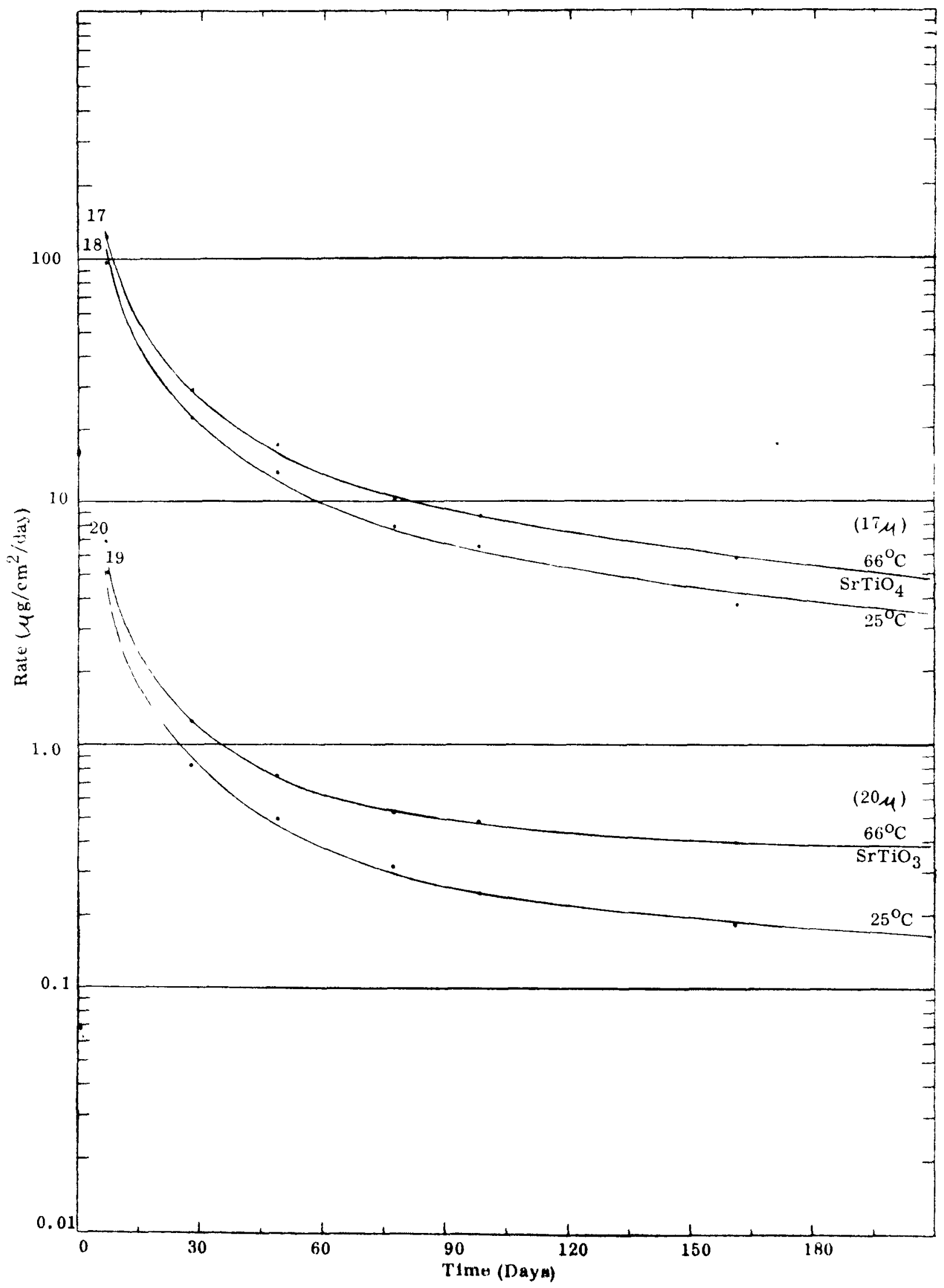

PIG. 7. STATIC SOLIMULTY OF STRONTUUM TITANATES IN 0.1 N HCI 


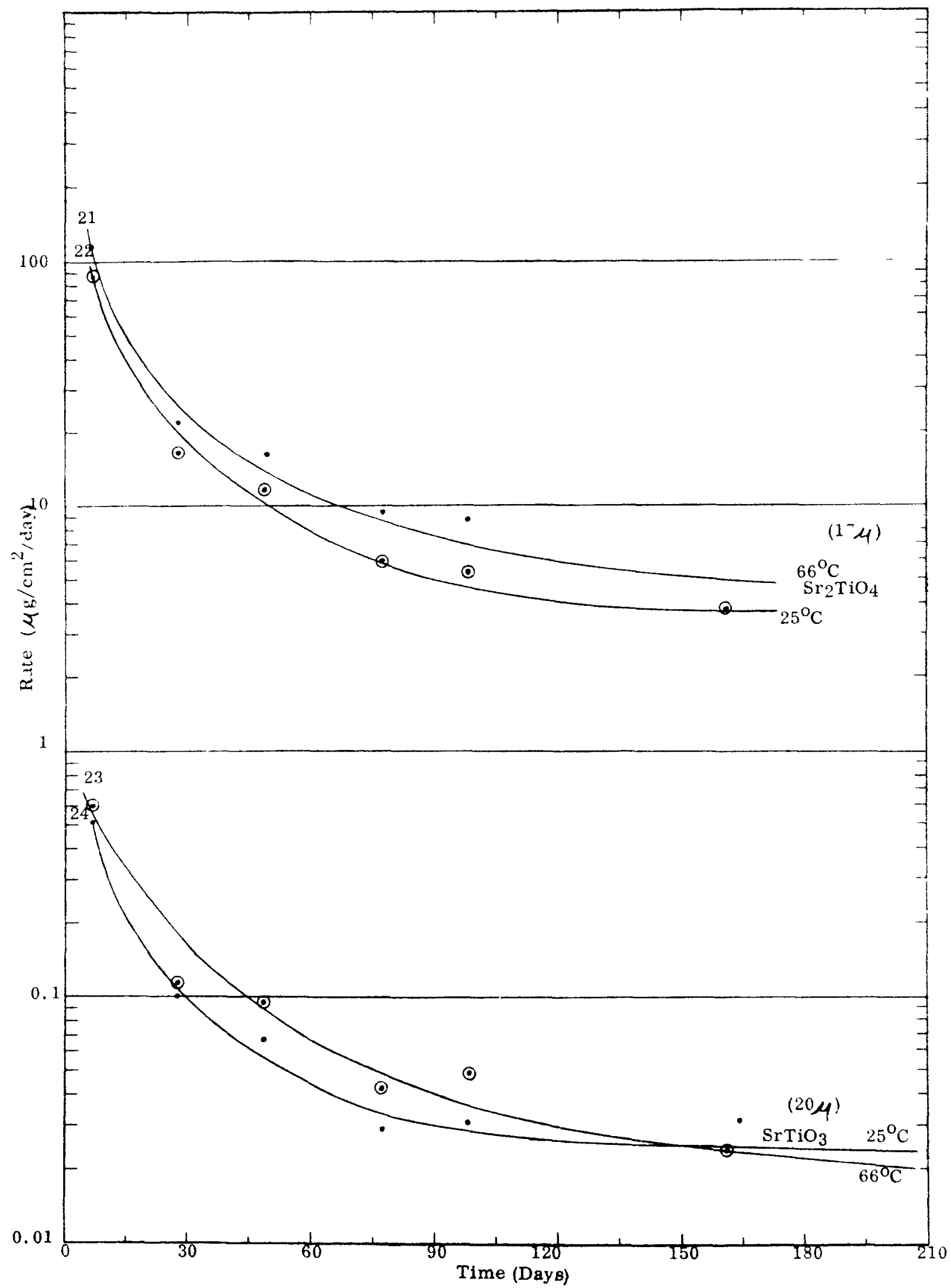

FIG. 8. STATIC SOLUBILITY OF STRONTIUM TITANATES IN DEIONIZED WATER 


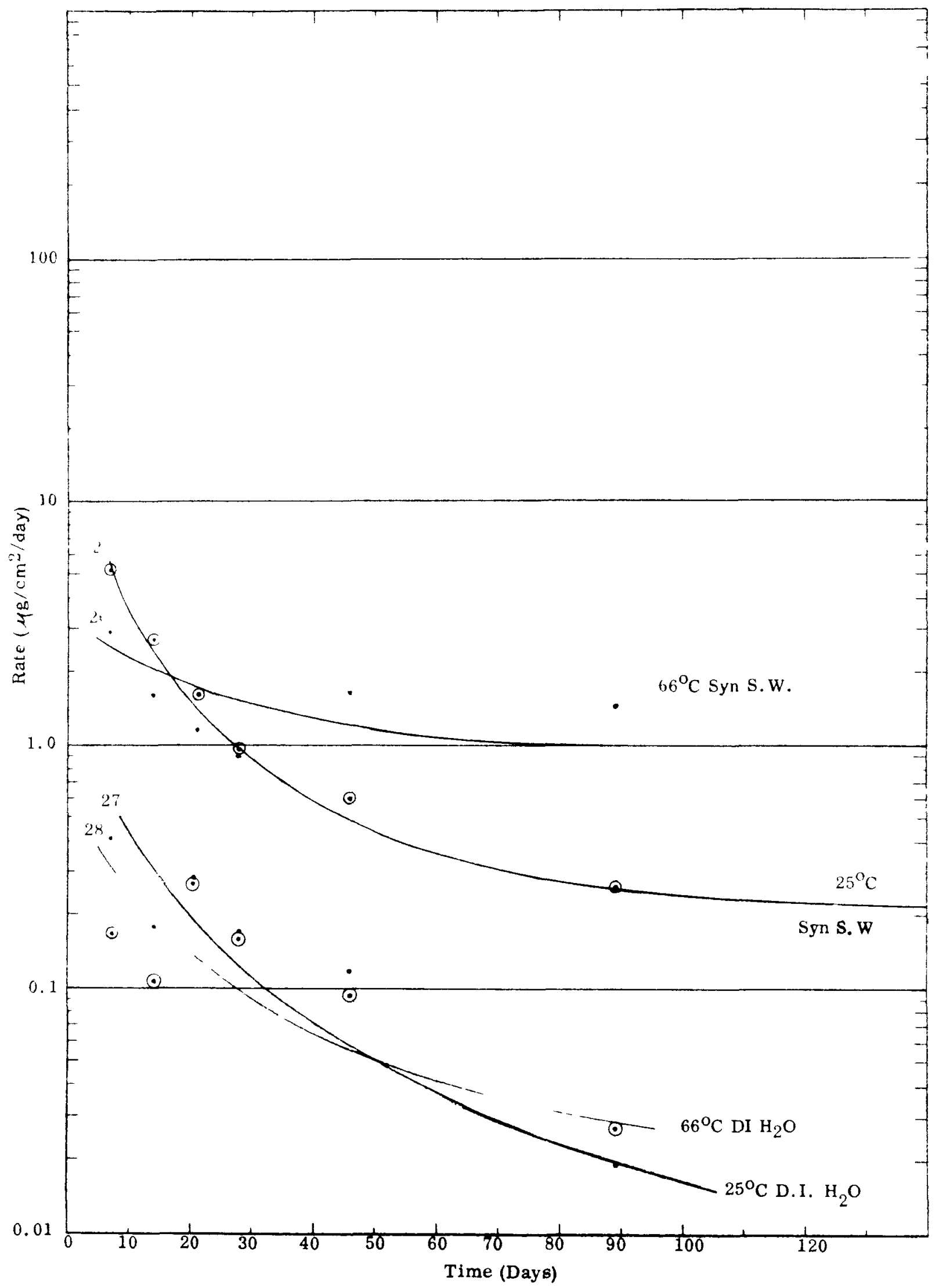

FIG. 9. STATIC SOLUBILITY OF STRONTIUM FLUORIDE (AVERAGE PARTICLE SIZE OF $35 \mu$ ) 


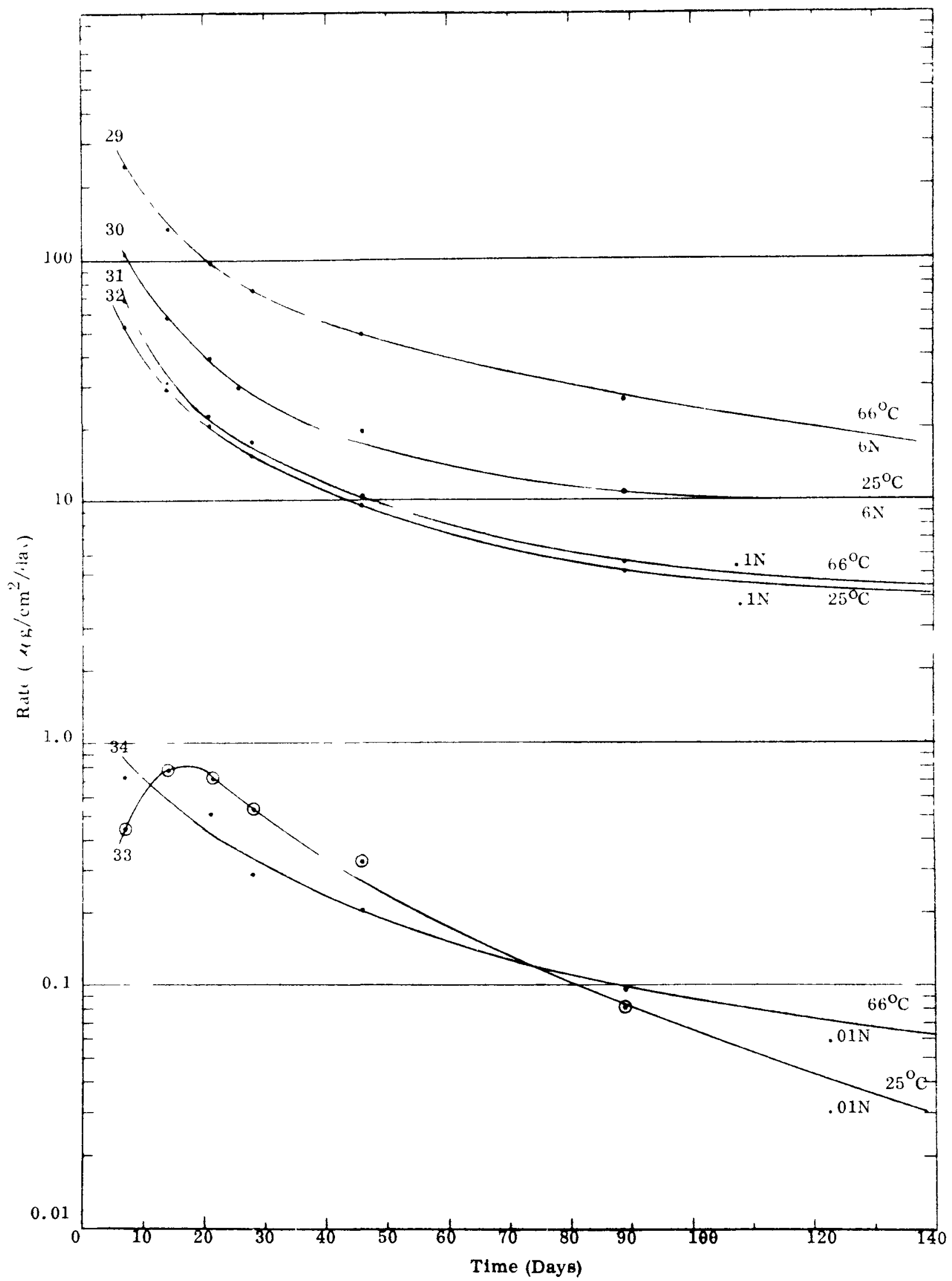

FIG. 10. STATIC SOLUBIITY OF SrF, IN HC1 SOLUTIONS (AVERAGE PARTICLE st/f. (1) . (1) 


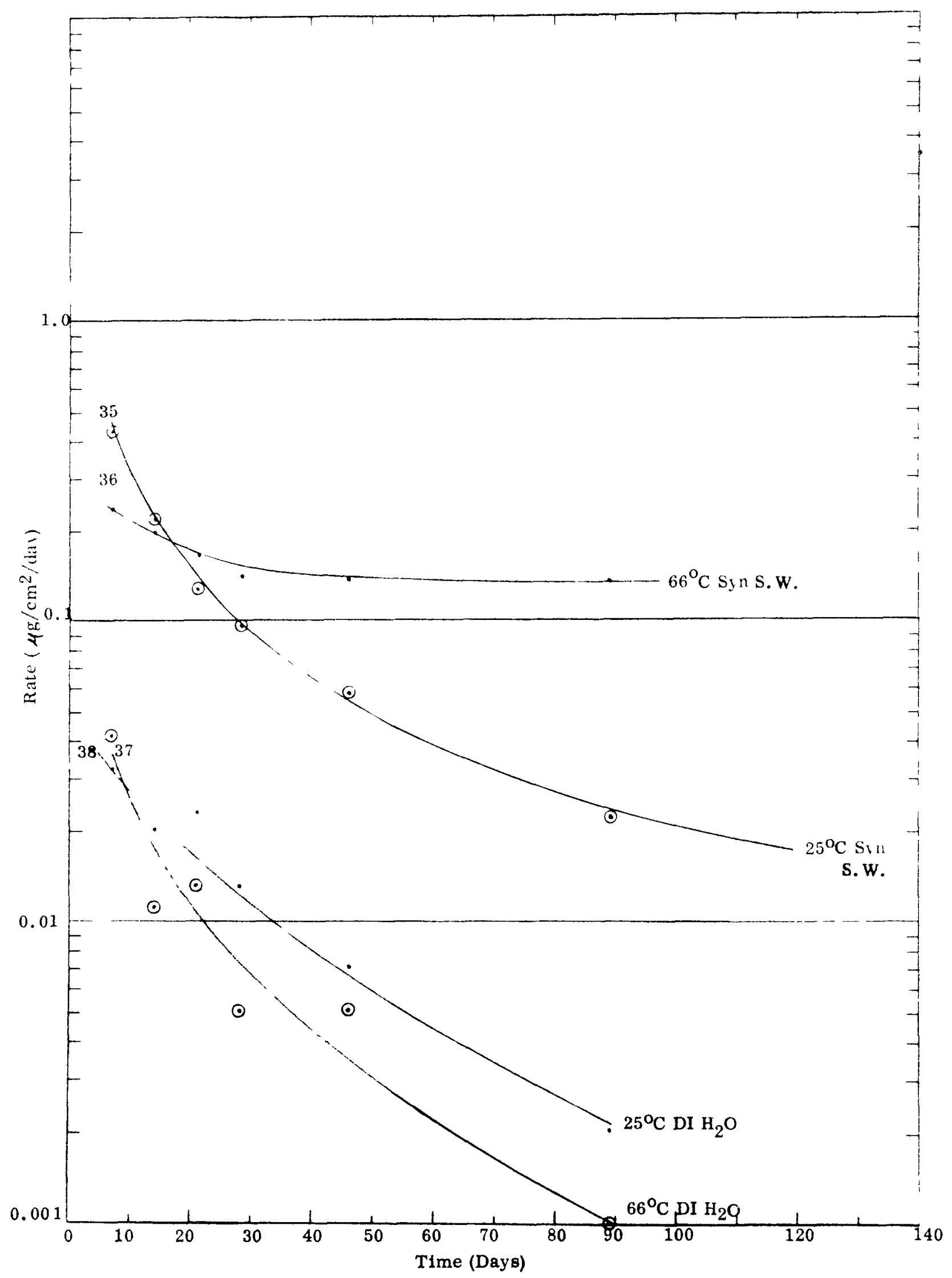

FIG. 11. STATIC SOLUBILITY OF $\mathrm{SrF}_{2}$ (AVERAGE PARTICLE SIZE OF 54) 


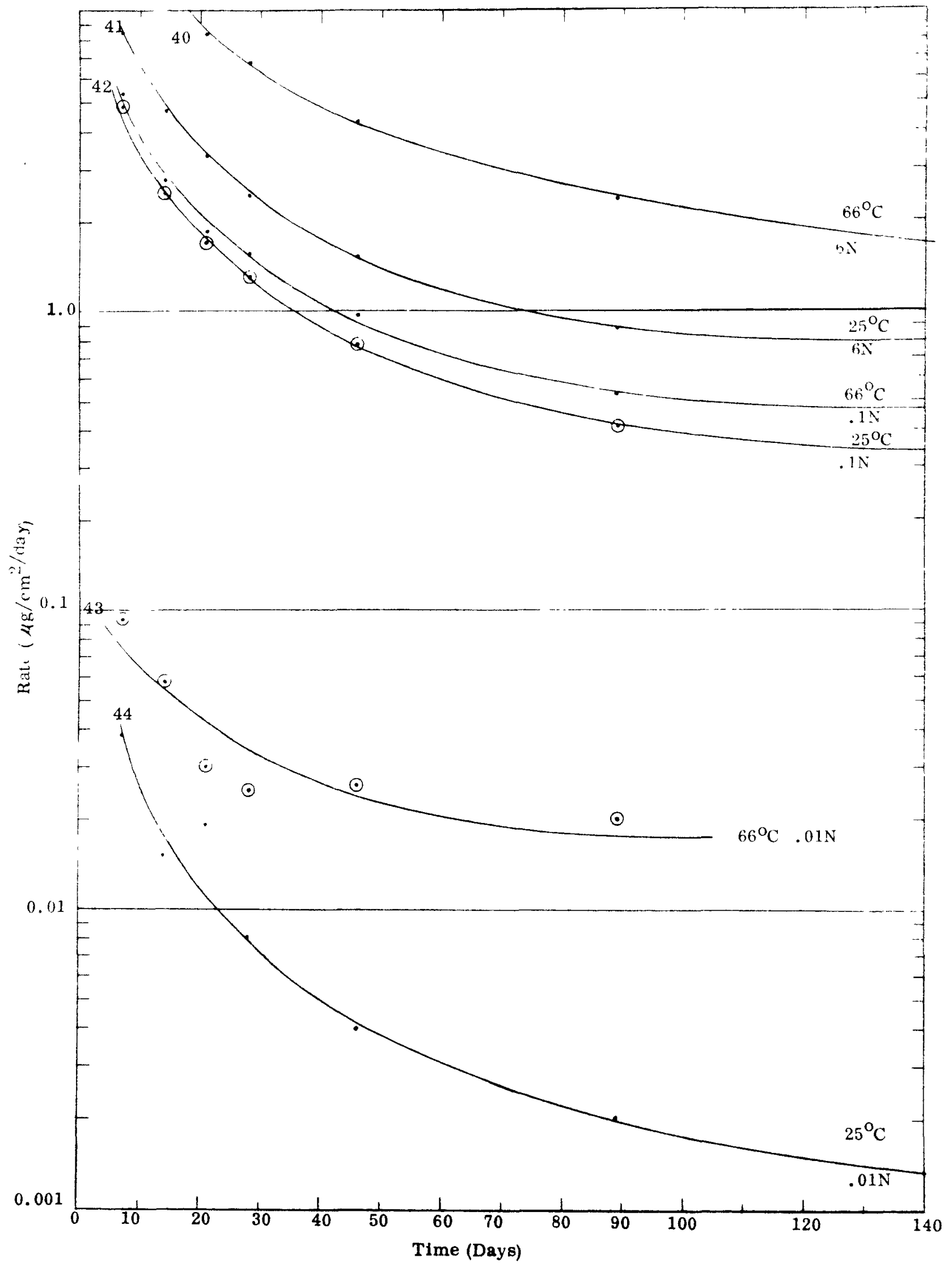

FIG. 12. STATIC SOLUBILITY OF $\mathrm{SrF}_{2}$ IN HC1 SOLUTIONS (AVERAGE PARTICLE 


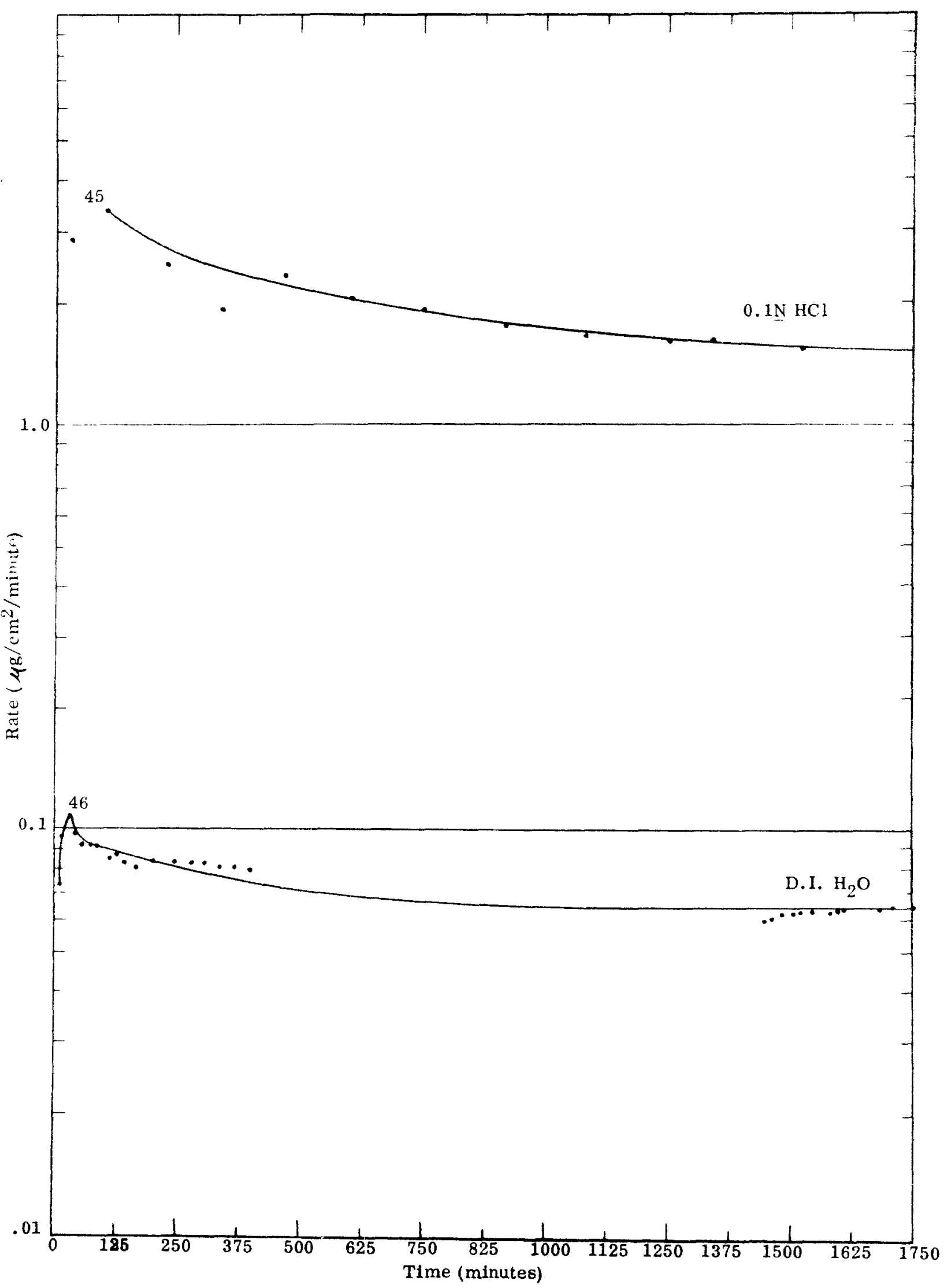

FIG. 13. DYNAMIC SOLUBILITY OF $\mathrm{SrF}_{2}$ (AVERAGE PARTICLE SIZE 35 4 ) 


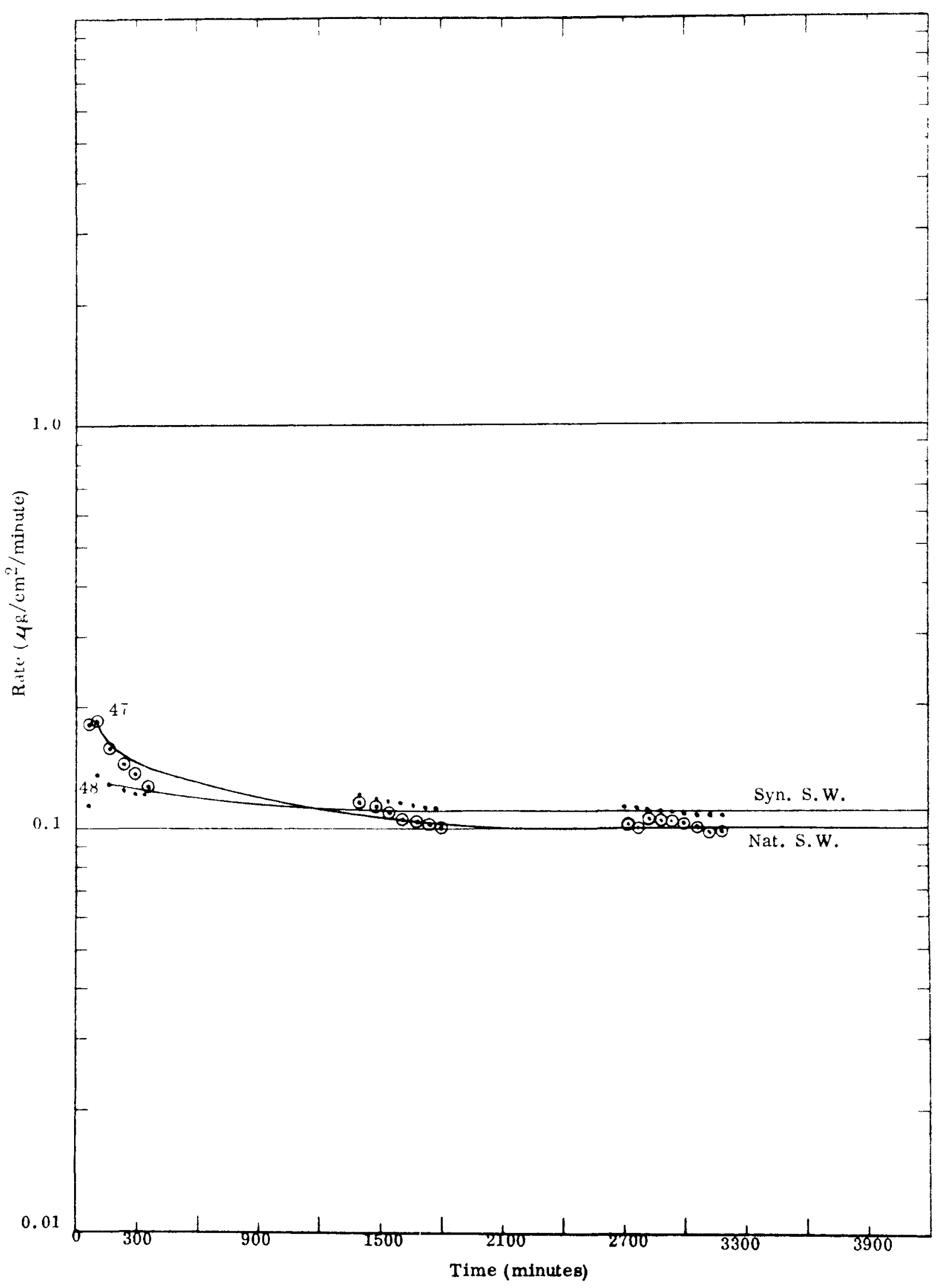

FIG. 14. DYNAMIC SOLUBILITY OF $\mathrm{SrF}_{2}$ (AVERAGE PARTIC LE SIZE 35 $\mu$ ) 
(1) $\mathrm{SrF}_{2}\left(5 \mu, 25^{\circ} \mathrm{C}\right) \quad 6 \mathrm{~N} \mathrm{HCl}>0.1 \mathrm{~N} \mathrm{HCl}>$ Syn. S.W. $>0.01 \times \mathrm{H} \mathrm{Cl}>\mathrm{D} . \mathrm{I}$. Water

(2) $\mathrm{SrF}_{2}\left(5 \mu, 66^{\circ} \mathrm{C}\right) 6 \mathrm{~N} \mathrm{HCl}>0.1 \mathrm{~N} \mathrm{HCl}>$ Syn. S.W. $>0.01 \mathrm{~N} \mathrm{HCl}>$ D.I. Water

(3) $\operatorname{SrF}_{2}\left(35 \mu, 25^{\circ} \mathrm{C}\right) 6 \mathrm{~N} \mathrm{HCl}>0.1 \mathrm{~N} \mathrm{HCl}>\mathrm{Syn} . \mathrm{S} . \mathrm{W} .>0.01 \mathrm{~N} \mathrm{HCl}>$ D.I. Watcl

(4) $\mathrm{SrF}_{2}\left(35 \mu, 66^{\circ} \mathrm{C}\right) 6 \mathrm{~N} \mathrm{HCl}>0.1 \mathrm{~N} \mathrm{HCl}>$ Syn. S.W. $>0.01 \mathrm{~N} \mathrm{HCl}>$ D.I. Water

(5) $\mathrm{SrF}_{2}\left(25\right.$ and $\left.66^{\circ} \mathrm{C}\right)$ Syn. S.W. $35 \mu_{1}>5 \mu$ (by approximately a factor of 10 )

(6) $\mathrm{SrF}_{2}\left(25\right.$ and $\left.66^{\circ} \mathrm{C}\right) \quad$ D.I. Water $35 \mu>54$ (by approximately a factor of 10$)$

(7) $\mathrm{SrF}_{2}\left(25\right.$ and $\left.66^{\circ} \mathrm{C}\right) \quad 0.01 \mathrm{~N} \mathrm{HCl} 35 \mu>5 \mu$ (by approximately a factor of 10 )

(8) $\mathrm{SrF}_{2}\left(25\right.$ and $\left.66^{\circ} \mathrm{C}\right) \quad 0.1 \mathrm{~N} \mathrm{HCl} 35 \mu>5 \mu$ (by approximately a factor of 10)

(9) $\operatorname{SrF}_{2}\left(25\right.$ and $\left.66^{\circ} \mathrm{C}\right) \quad 6 \mathrm{~N} \mathrm{HCl} 35 \mu>5 \mu$ (by approximately a factor of 10)

(10) $\operatorname{SrTiO}_{3}\left(25^{\circ} \mathrm{C}, 20 \mu\right) 0.1 \mathrm{~N} \mathrm{HCl}>$ Syn. S.W. = Nat. S.W. $>$ D.I. Water

(11) $\operatorname{SrTiO}_{3}\left(66^{\circ} \mathrm{C}, 20 \mu_{1}\right) 0.1 \mathrm{~N} \mathrm{HCl}>\mathrm{Syn} . \mathrm{S} . \mathrm{W} .=$ Nat. S.W. $>$ D.I. Water

(12) $\mathrm{Sr}_{2} \mathrm{TiO}_{4}\left(66^{\circ} \mathrm{C}, 17 \mu\right) 0.1 \mathrm{~N} \mathrm{HCl}=$ Syn. S. W. = Nat. S. W. = D.I. Water

(13) $\mathrm{Sr}_{2} \mathrm{TiO}_{4}\left(66^{\circ} \mathrm{C}, 17 \mu\right) 0.1 \mathrm{~N} \mathrm{HCl}=$ Syn. S. W. = Nat. S. W. = D.I. Water

(14) Synthetic Sea Water $\left(25^{\circ} \mathrm{C}\right)$

(15) Synthetic Sea Water $\left(66^{\circ} \mathrm{C}\right)$

(16) Deionized Water $\left(25^{\circ} \mathrm{C}\right)$

(17) Deionized Water $\left(66^{\circ} \mathrm{C}\right)$

(18) $0.1 \mathrm{~N} \mathrm{HCl}\left(25^{\circ} \mathrm{C}\right)$

(19) $0.1 \mathrm{~N} \mathrm{HCl}\left(66^{\circ} \mathrm{C}\right)$
$\mathrm{Sr}_{2} \mathrm{TiO}_{4}>35 \mu \mathrm{SrF}_{2}>\mathrm{SrTiO}_{3}>5 \mu \mathrm{SrF}_{2}$ $\mathrm{Sr}_{2} \mathrm{TiO}_{4}>35 \mu \mathrm{SrF}_{2}>5 \mu_{4} \mathrm{SrF}_{2}>\mathrm{SrTiO}_{3}$ $\mathrm{Sr}_{2} \mathrm{TiO}_{4}>\mathrm{SrTiO}_{3}>35 \mu \mathrm{SrF}_{2}>54 \mathrm{SrF}_{2}$ $\mathrm{Sr}_{2} \mathrm{TiO}_{4}>\mathrm{SrTiO}_{3}>35 \mu \mathrm{SrF}_{2}>5 \mu \mathrm{SrF}_{2}$ $\mathrm{Sr}_{2} \mathrm{TiO}_{4} \approx 35 \mu \mathrm{SrF}_{2}>5 \mu_{1} \mathrm{SrF}_{2}>\mathrm{SrTiO}_{3}$ $\mathrm{Sr}_{2} \mathrm{TiO}_{4} \approx 35 \mu \mathrm{SrF}_{2}>5 \mu \mathrm{SrF}_{2}>\mathrm{SrTiO}_{3}$

The short term solubility rates of the three fuels tested under dy namic conditions exhibited identical trends in the solvents examined. The rate of $\mathrm{Sr}_{2} \mathrm{TiO}_{4}$ was the highest, whereas, $\mathrm{SrTiO}_{3}$ was the lowest. The short term solubility rates in the four solvents were found to vary according to the fuel tested. All three fuels exhibited the maximum solubility in $\mathrm{HCl}$, but $\mathrm{SrF}_{2}$ was least soluble in deionized water, whereas, the solubility of the titanates was greater in deionized water than in either of the two sea waters. This dependence of $\mathrm{SrF}_{2}$ on the concentration of anions (halogens) in the solvents was also noted in the static test results.

All fuels, whether measured under dynamic or static conditions, have an initial high solubility rate which subsequently decreased as a function of time. This was observed when powders were pre-washed and remained unwashed and for all solvents. During the first few minutes of dissolution, a lew of the short term dynamic tests indicated that the solubility rate was increasing to a maximum before the long term decrease in rate was affected. This "leveling off" or the indication of a long term constant rate was observed in most of the dissolution tests.

The total surface area exposed per gram of material was found to have a 
significant effect on the solubility rate. The dissolution rate of $\mathrm{Sr}_{2} \mathrm{~F}_{2}$ particles which had an average diameter of 35 microns was an order of magnitude greater than the rate of 5 microns, average diameter particles for all solutions tested. This trend of smaller exposed surface area resulting in higher rates $\$ 4 \mathrm{~g}$ fuel $/ \mathrm{cm}^{2}$ of surface area/unit time) was in agreement with the data previously reported for $\mathrm{SrTiO}_{3}$ pellets. The surface area per gram of fuel was much smaller for the pellets and consequently the solubility rates of the titanate pellets were reported higher than those rate measurements conducted on titanate powders in this study.

Temperature had little effect on the sequence of solubility of $\mathrm{Sr}_{2}$ in the test solutions. This observation was noted for both 5- and 35-micron size particles. Also, the temperature did not effect the observed order of magnitude difference between the solubility rates of the two particle sizes tested.

Temperature was found to have only a minor effect on the solubility characteristics of the titanate fuels. Measurements made at $66^{\circ} \mathrm{C}$ shifted the solubility rate sequence in synthetic sea water of $\mathrm{SrTiO}_{3}$ and $5 \mu \mathrm{SrF} \mathrm{F}_{2}$. The only time a $25^{\circ} \mathrm{C}$ measurement was found to have a higher solubility rate than the $66^{\circ} \mathrm{C}$ measurement was for both 5- and 35-micron diameter $\mathrm{SrF}_{2}$ particles in deionized water. As was noted during the short term dynamic dissolution studies, $\mathrm{SrF}_{2}$ dissolution in deionized water was the lowest and appeared to be directly dependent upon the halide concentration in the test solution. A similar dependence for titanate fuels in deionized water was not observed.

A significant difference between the rates in synthetic and natural sea water was not noted. Both $\mathrm{Sr}_{2} \mathrm{TiO}_{4}$ and $\mathrm{SrTiO}_{3}$ powders at $25^{\circ}$ and $66^{\circ} \mathrm{C}$ exhibited almost identical dissolution rates as a function of time. Small differences, which varied as a function of the initial solubility, were observed in the dissolution rates of the short term measurements.

A summary of all the test results is presented in Tables IV and V. The percent dissolved from the surface of each size particle has been calculated from the start of the dissolution to that time at which the rate became constant. The remaining particle size will then dissolve at the steady state dissolution rate. Knowledge of the particle size and the rate of dissolution will enable an estimate of the time required for the complete dissolution of the radioactive material. 


\section{TABLE IV}

Long Term Static Dissolution of Strontium Fuels

\begin{tabular}{|c|c|c|c|c|c|c|}
\hline \multirow[b]{2}{*}{$\begin{array}{l}\text { Original } \\
\text { Particle } \\
\text { Size }(\mu) \\
\end{array}$} & \multirow[b]{2}{*}{$\begin{array}{c}\text { Temperature } \\
\left({ }^{\circ} \mathrm{C}\right) \\
\end{array}$} & \multirow[b]{2}{*}{$\begin{array}{c}\begin{array}{c}\text { Dissolver } \\
\text { Solution }\end{array} \\
\end{array}$} & \multirow[b]{2}{*}{$\begin{array}{l}\text { Fuel } \\
\text { Form } \\
\end{array}$} & \multirow[b]{2}{*}{$\begin{array}{c}\text { Dissolved, } \\
\text { Unsteady State } \\
(\sim \%) \\
\end{array}$} & \multicolumn{2}{|c|}{ At Steady State } \\
\hline & & & & & $\begin{array}{l}\text { Calculated } \\
\text { Size }(\mu)\end{array}$ & $\begin{array}{c}\text { Dissolution Rate } \\
\left(\mu \mathrm{g} / \mathrm{cm}^{2} / \text { day }\right)\end{array}$ \\
\hline 35 & 25 & SSW & $\mathrm{SrF}_{2}$ & 0.81 & 35 & 0.25 \\
\hline 35 & 66 & SSW & $\mathrm{SrF}_{2}$ & 1.7 & 34.6 & 1.0 \\
\hline 35 & 25 & DrW & $\mathrm{SrF}_{2}$ & 0.099 & 35 & 0.012 \\
\hline 35 & 66 & DIW & $\mathrm{SrF}_{2}$ & 0.078 & 35 & 0.018 \\
\hline 35 & 25 & $6.0 \mathrm{~N} \mathrm{HC1}$ & $\mathrm{SrF}_{2}$ & 26.4 & 31.5 & 10.0 \\
\hline 35 & 66 & $6.0 \mathrm{~N} \mathrm{HC1}$ & $\operatorname{SrF}_{2}$ & 70.2 & 27 & 17.0 \\
\hline 35 & 25 & $0.1 \underline{\mathrm{N}} \mathrm{HC} 1$ & $\operatorname{SrF}_{2}$ & 12.3 & 33.7 & 4.0 \\
\hline 35 & 66 & $0.1 \underline{\mathrm{N}} \mathrm{HC} 1$ & $\mathrm{SrF}_{2}$ & 12.9 & 33.5 & 4.5 \\
\hline 35 & 25 & $0.01 \underline{\mathrm{N}} \mathrm{HCl}$ & $\mathrm{SrF}_{2}$ & 0.254 & $35-$ & 0.02 \\
\hline 35 & 66 & $0.01 \underline{\mathrm{N}} \mathrm{HCl}$ & $\mathrm{SrF}_{2}$ & 0.266 & $35-$ & 0.06 \\
\hline 5 & 25 & SSW & $\mathrm{SrF}_{2}$ & 1.46 & 4.9 & 0.014 \\
\hline 5 & 66 & SSW & $\mathrm{SrF}_{2}$ & 2.56 & 4.8 & 0.13 \\
\hline 5 & 66 & DIW & $\mathrm{SrF}_{2}$ & 0.07 & 5.0 & 0.0007 \\
\hline 5 & 25 & DIW & $\mathrm{SrF}_{2}$ & 0.11 & 5.0 & 0.0015 \\
\hline 5 & 66 & $6 \underline{\mathrm{N} \mathrm{HC} 1}$ & $\mathrm{SrF}_{2}$ & 85.0 & 1.25 & 1.7 \\
\hline 5 & 25 & $6 \underline{\mathrm{NHC1}}$ & $\mathrm{SrF}_{2}$ & 32.9 & 4.2 & 0.8 \\
\hline 5 & 25 & $0.1 \mathrm{~N} \mathrm{HC} 1$ & $\mathrm{SrF}_{2}$ & 17.4 & 4.7 & 0.33 \\
\hline 5 & 66 & $0.1 \mathrm{NHCl}$ & $\mathrm{SrF}_{2}$ & 19.7 & 4.6 & 0.48 \\
\hline
\end{tabular}


TABLE IV (Cont)

\begin{tabular}{|c|c|c|c|c|c|c|c|}
\hline & & & & & & At $S$ & eady State \\
\hline & $\begin{array}{l}\text { Original } \\
\text { Particle } \\
\text { Size }(\mu) \\
\end{array}$ & $\begin{array}{c}\text { Temperature } \\
\left({ }^{\circ} \mathrm{C}\right) \\
\end{array}$ & $\begin{array}{c}\text { Dissolver } \\
\text { Solution } \\
\end{array}$ & $\begin{array}{l}\text { Fuel } \\
\text { Form } \\
\end{array}$ & $\begin{array}{c}\text { Dissolved, } \\
\text { Unsteady State } \\
(\sim \%) \\
\end{array}$ & $\begin{array}{l}\text { Calculated } \\
\text { Size }(\mu)\end{array}$ & $\begin{array}{l}\text { Dissolution Rate } \\
\left(\mu \mathrm{g} / \mathrm{cm}^{2} / \text { day }\right)\end{array}$ \\
\hline & 5 & 25 & $0.01 \underline{\mathrm{N}} \mathrm{HCl}$ & $\mathrm{SrF}_{2}$ & 0.068 & 5.0 & 0.0012 \\
\hline & 5 & 66 & $0.01 \underline{\mathrm{N}} \mathrm{HC} 1$ & $\mathrm{SrF}_{2}$ & 0.47 & 4.98 & 0.018 \\
\hline & 20 & 26 & DIW & $\mathrm{SrTiO}_{3}$ & 0.21 & 20 & 0.023 \\
\hline & 20 & 66 & DIW & $\mathrm{SrTiO}_{3}$ & 0.35 & 19.8 & 0.02 \\
\hline & 20 & 25 & SSW & $\mathrm{SrTiO}_{3}$ & 0.37 & 19.8 & 0.045 \\
\hline & 20 & 66 & SSW & $\mathrm{SrTiO}_{3}$ & 0.83 & 19.7 & 0.085 \\
\hline Z & 20 & 25 & NSW & $\mathrm{SrTiO}_{3}$ & 0.40 & 19.8 & 0.049 \\
\hline w & 20 & 66 & NSW & $\mathrm{SrTiO}_{3}$ & 0.72 & 19.7 & 0.087 \\
\hline 1 & 20 & 25 & $0.1 \underline{\mathrm{N}} \mathrm{HC} 1$ & $\mathrm{SrTiO}_{3}$ & 2.09 & 19.5 & 0.17 \\
\hline & 20 & 66 & $0.1 \underline{\mathrm{N}} \mathrm{HC} 1$ & $\mathrm{SrTiO}_{3}$ & 3.13 & 19.4 & 0.39 \\
\hline & 17 & 25 & DIW & $\mathrm{SrTiO}_{4}$ & 78.8 & 10 & 3.8 \\
\hline & 17 & 66 & DIW & $\mathrm{Sr}_{2} \mathrm{TiO}_{4}$ & 95 & 6.4 & 4.5 \\
\hline & 17 & 25 & SSW & $\mathrm{Sr}_{2} \mathrm{TiO}_{4}$ & 83.5 & 9.1 & 3.8 \\
\hline & 17 & 66 & SSW & $\mathrm{Sr}_{2} \mathrm{TiO}_{4}$ & $>95$ & $\sim 5$ & 5.2 \\
\hline & 17 & 25 & NSW & $\mathrm{Sr}_{2} \mathrm{TiO}_{4}$ & 75.6 & 11 & 3.3 \\
\hline & 17 & 66 & NSW & $\mathrm{Sr}_{2} \mathrm{TiO}_{4}$ & 95 & 6.4 & 4.8 \\
\hline & 17 & 25 & $0.1 \mathrm{~N} H C 1$ & $\mathrm{Sr}_{2} \mathrm{TiO}_{4}$ & 78.8 & 10 & 3.5 \\
\hline & 17 & 66 & $0.1 \mathrm{~N} \mathrm{HC1}$ & $\mathrm{Sr}_{2} \mathrm{TiO}_{4}$ & 97.6 & 4.9 & 4.8 \\
\hline
\end{tabular}




\section{TABLE V}

Short Term Dynamic Dissolution of Strontium Fuels

\begin{tabular}{|c|c|c|c|c|c|c|c|}
\hline & \multirow[b]{2}{*}{$\begin{array}{l}\text { Original } \\
\text { Particle } \\
\text { Size }(\mu) \\
\end{array}$} & \multirow[b]{2}{*}{$\begin{array}{c}\text { Temperature } \\
\left({ }^{\circ} \mathrm{C}\right) \\
\end{array}$} & \multirow[b]{2}{*}{$\begin{array}{c}\begin{array}{c}\text { Dissolver } \\
\text { Solution }\end{array} \\
\end{array}$} & \multirow[b]{2}{*}{$\begin{array}{l}\text { Fuel } \\
\text { Form } \\
\end{array}$} & \multirow[b]{2}{*}{$\begin{array}{c}\text { Dissolved, } \\
\text { Unsteady State } \\
(\sim \%) \\
\end{array}$} & \multicolumn{2}{|c|}{ At Steady State } \\
\hline & & & & & & $\begin{array}{l}\text { Calculated } \\
\text { Size }(\mu) \\
\end{array}$ & $\begin{array}{c}\text { Dissolution Rate } \\
\left(\mu \mathrm{g} / \mathrm{cm}^{2} / \text { day }\right)\end{array}$ \\
\hline & 96 & 25 & $0.1 \mathrm{~N} \mathrm{HC} 1$ & $\mathrm{SrTiO}_{3}$ & 0.547 & 95 & 41.8 \\
\hline & 96 & 25 & DIW & $\mathrm{SrTiO}_{3}$ & 0.109 & 95.5 & 4.5 \\
\hline & 96 & 25 & SSW & $\mathrm{SrTiO}_{3}$ & 0.083 & 95.7 & 4.6 \\
\hline 总 & 96 & 25 & NSW & $\mathrm{SrTiO}_{3}$ & 0.039 & 95.9 & 3.7 \\
\hline 足 & 100.5 & 25 & $0.1 \underline{\mathrm{NHC} 1}$ & $\mathrm{Sr}_{2} \mathrm{TiO}_{4}$ & 43.64 & 86 & 2448 \\
\hline S & 100.5 & 25 & DIW & $\mathrm{Sr}_{2} \mathrm{TiO}_{4}$ & 3.18 & 100.3 & 360 \\
\hline$\stackrel{0}{0}$ & 100.5 & 25 & NWS & $\mathrm{Sr}_{2} \mathrm{TiO}_{4}$ & 2.80 & 100.3 & 288 \\
\hline & 100.5 & 25 & SSW & $\mathrm{Sr}_{2} \mathrm{TiO}_{4}$ & 1.80 & 100.4 & 194 \\
\hline & 35 & 25 & $0.1 \mathrm{~N} \mathrm{HC} 1$ & $\mathrm{SrF}_{2}$ & 32.5 & 31 & 2304 \\
\hline & 35 & 25 & DIW & $\mathrm{SrF}_{2}$ & 1.22 & 34.7 & 93.6 \\
\hline & 35 & 25 & NSW & $\mathrm{SrF}_{2}$ & 5.08 & 34.2 & 144 \\
\hline & 35 & 25 & SSW & $\mathrm{SrF}_{2}$ & 4.51 & 34.2 & 165.6 \\
\hline
\end{tabular}




\section{References}

1. P. E. Zigman et al, "Radioactivity Release From Radionuclide Power Sources," USNRDL-TR-745, April 1964.

2. J. Bloom and C. Riggs, "Significance of Solubility Data in Determining Rates of Solution and Diffusion of Strontium-90 in the Form of Strontium Titanate," Martin Company, Baltimore, Maryland, RP-62-5-45.

3. MND-3062-9, "Process Development of Sr-90 Space Fuel," August 15, 1965.

4. Navy Department Specification 44T276, 7-1-1940.

5. Sverdrup, et al, "The Oceans," 1942, Prentice-Hall, Inc. 